\title{
IMPACTS OF PETROLEUM, PETROLEUM COMPONENTS, AND DISPERSANTS ON ORGANISMS AND POPULATIONS
}

By Steven A. Murawski, Martin Grosell, Cynthia Smith, Tracey Sutton, Kenneth M. Halanych, Richard F. Shaw, and Charles A. Wilson

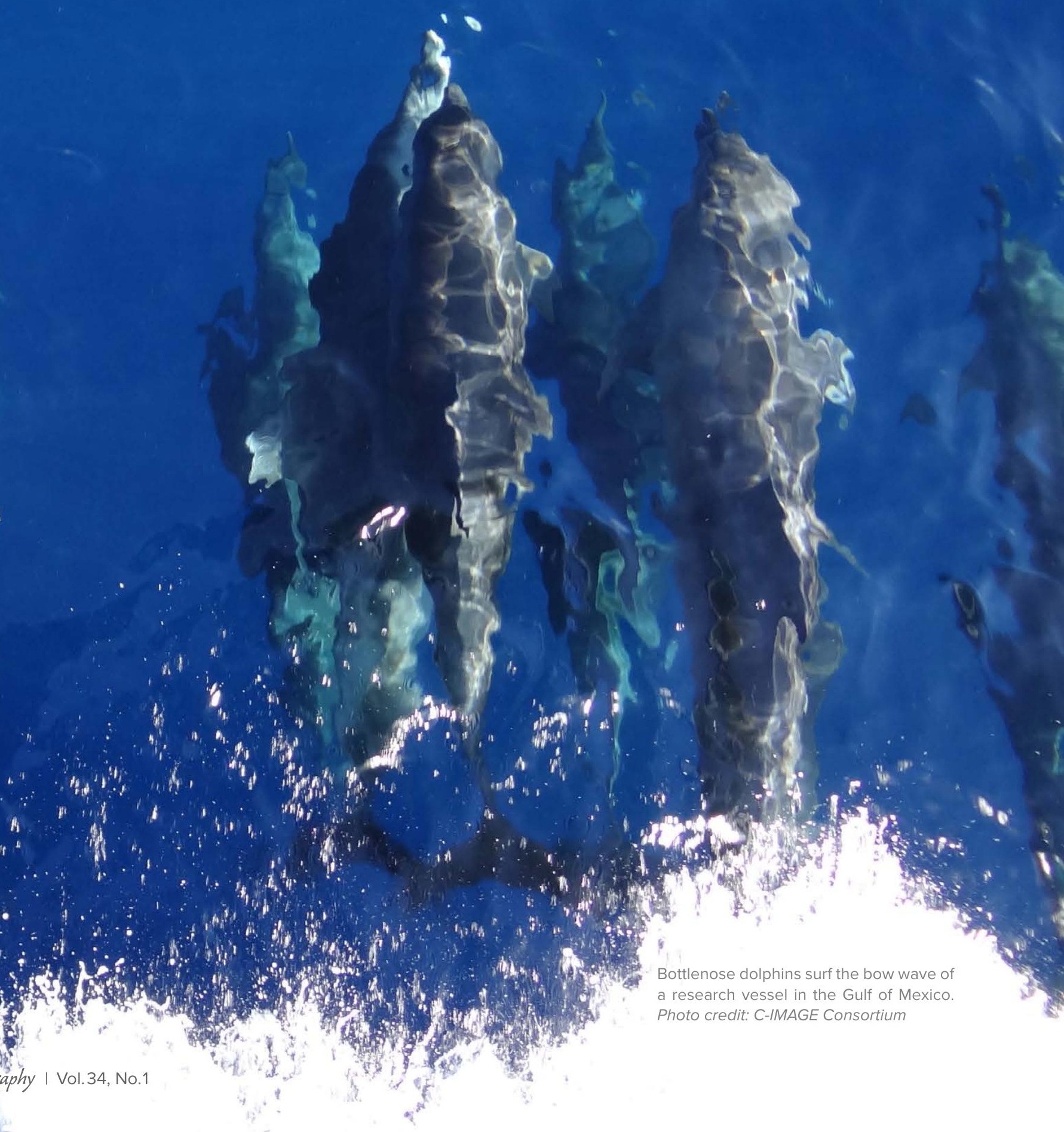


ABSTRACT. Following the Deepwater Horizon blowout, oil, degraded oil, oil mixed with dispersants, and management responses to the spill affected a variety of Gulf of Mexico organisms. This review provides examples of various documented impacts, common patterns, and trends across organisms and/or their environments, and discusses future implications as well as directions for future research. Organism effects are generally characterized as lethal and sublethal. Sublethal can be short term, long term, or permanent and multigenerational. We present individual examples of effects on behavioral response, olfaction, vision, cardiac function, and gene shift, based on research done in laboratories, mesocosm settings, and the field. Future research should emphasize collection and analysis of routine toxicological baselines and examine how and if molecular impacts cascade up to populations. This research will require development of rapid molecular tools and testing procedures to determine exposure compared to field-relevant exposure levels and to be able to extrapolate laboratory results to the field, especially given the mosaic of differing contaminant concentrations (below, at, or exceeding critical concentrations that result in lethal or sublethal effects) occurring in the environment. Recent chemical studies have identified a detectable suite of polycyclic aromatic hydrocarbon metabolites for which there are no toxicity data; further research is needed to determine their impacts on food webs.

\section{INTRODUCTION}

Approaches for assessing impacts of significant oil spills on the natural world, and oil spill research generally, lurch forward rapidly but unevenly in the wakes of infrequent large spills in a "punctuated equilibrium" of sorts. For example, in the decades following the 1989 Exxon Valdez spill, a new appreciation for the secondary effects of oil on predator-prey dynamics and the effects of both oil pollution and response measures on the integrity and productivity of affected habitats and populations emerged as a paradigm shift in oil spill science (Peterson et al., 2003). Of course, each large spill is idiosyncratic, and the mix of topical issues associated with each does not necessarily move the field forward in any predictable path. Likewise, because of the lack of sustained funding during long periods when large spills do not occur, agencies find it challenging to proactively fund science consistent with the matrix of emerging threats or to keep pace with innovations and trends in the oil and gas production industries (ICCOPR, 2015; Murawski et al., 2020). Such is the case with the Deepwater Horizon (DWH) oil spill in the Gulf of Mexico, the first and largest ultra-deepwater $(\geq 1,500 \mathrm{~m}$ water depth) well blowout in global history (Lubchenco et al., 2012). While originat- ing in the deep sea, spilled oil and oil dispersing chemicals from DWH eventually polluted ecosystems ranging from the meso- to the epipelagic water column; the deep-sea benthos; the continental shelves; and inshore habitats, including beaches, marshes, and estuaries (Deepwater Horizon Natural Resource Damage Assessment Trustees, 2016; Murawski et al., 2021). Impacts to marine and estuarine species and habitats resulted from direct exposure to fresh, weathered, and fresh and chemically dispersed oil, and indirectly from degraded habitats and as a result of response measures intended to mitigate spill effects.

A unique feature of the DWH spill was the significant involvement of the academic community both in response to the ongoing spill and especially in documenting and evaluating impacts to biota. This community of scientists was rarely involved in oil spill response prior to DWH except in narrowly prescribed contracting roles with response agencies. One consequence of the funding largesse available to independent scientists, through grants from the Gulf of Mexico Research Initiative (GoMRI, which spent \$500 million) and other funders, has been to infuse this research with a broad array of advanced tools, technologies, and approaches originally developed for use in other fields, and to involve a science community not usually invested in oil spill applications (e.g., Murawski et al., 2018; Grosell et al., 2020; Kostka et al., 2020). This research has included, for example, the application of advanced genomic tools to quantify bacterial community change, as well as the application of a host of genomic, morphological, physiological, and immune system tools to determine how oil exposure affected organisms at the subcellular to organismal levels (Figure 1). Understanding toxicological effects and their implications for survival, growth, and reproduction permits an evaluation of changes in the overall fitness of populations (Deepwater Horizon Natural Resource Damage Assessment Trustees, 2016; Beyer et al., 2016; Grosell and Pasparakis, 2021). Definition of the cascade of effects from subcellular to population and ecosystem levels reflects an increasing appreciation for the modes of action of pollutants as they sequentially affect organs, body systems, and outcomes (Figure 1), leading to both lethal and sublethal endpoints.

Traditional assessments of environmental impacts of oil spills have often been based on evaluating concentrations of pollutants required to kill $50 \%$ of subject (and standardized) test animals in short-term laboratory-based studies to estimate lethal concentrations or other effective concentrations (i.e., $\mathrm{LC}_{50} / \mathrm{EC}_{50}$; Bejarano et al., 2014; Bejarano and Barron, 2014; Grosell et al., 2020; NASEM, 2020). These levels typically are then extrapolated to concentrations of pollutants in the environment to project population-level impacts of a particular spill (Deepwater Horizon Natural Resource Damage Assessment Trustees, 2016; Barron et al., 2020). During and subsequent to the DWH oil spill, considerable research was conducted to assess traditional biomarkers of biological endpoints (e.g., Mitchelmore et al., 2020) and to develop and apply suites of sublethal indicators of aquatic biota health in order to understand the induction of health effects involving immune responses, 
genomic changes, reproductive success, growth effects, and impairment of various organ systems in affected species (e.g., Whitehead et al., 2012; Sherwood et al., 2017; Grosell and Pasparakis, 2021; Rodgers et al., 2021). Rather than focusing only on direct mortality outcomes for individuals and populations, these studies have emphasized the importance of understanding mechanisms of induction and regulation of organism homeostasis in the presence of oil and dispersed oil at sublethal concentrations. Field-level research combined with controlled laboratory analyses revealed how organismal response mechanisms can be used to explain symptomology observed in areas and species affected by the spill (Deak, 2020; Raimondo et al., 2020). Additionally, longitudinal studies over the ensuing decade since DWH have documented changes in populations and communities of species potentially affected by the spill and by a host of simultaneous co-stressors (Schwing et al., 2020; Murawski et al., 2021b). Ascribing post-spill decadal changes in populations to oil spill impacts is challenging, but some obvious population and community changes point to the spill as a likely suspect.

Here, we highlight examples of exposure effects on behavioral responses, olfaction, cardiac function, disease progression, and other morphological and physiological consequences and findings from laboratory experiments and mesocosm settings and from field data. Further, we describe in general terms how various habitats affected by the DWH spill and species populations inhabiting them have fared, particularly emphasizing longitudinal monitoring of abun- dance and demography over the decade subsequent to the DWH spill, which is in itself unique for oil spill impact monitoring. Assessments of impacts of future oil spills will be guided by discoveries made as a consequence of a decade of postDWH oil spill research funded by the Gulf of Mexico Research Initiative, the Natural Resource Damage Assessment Trustees, and the parties responsible for the DWH accident.

\section{EVOLVING PERSPECTIVES FROM DWH-RELATED RESEARCH \\ ON THE MEASUREMENT AND ASSESSMENT OF ECOTOXICOLOGICAL EFFECTS}

Toxic effects of crude oil and derivative products on marine life have long been appreciated and assessed as significant negative consequences of oil spills

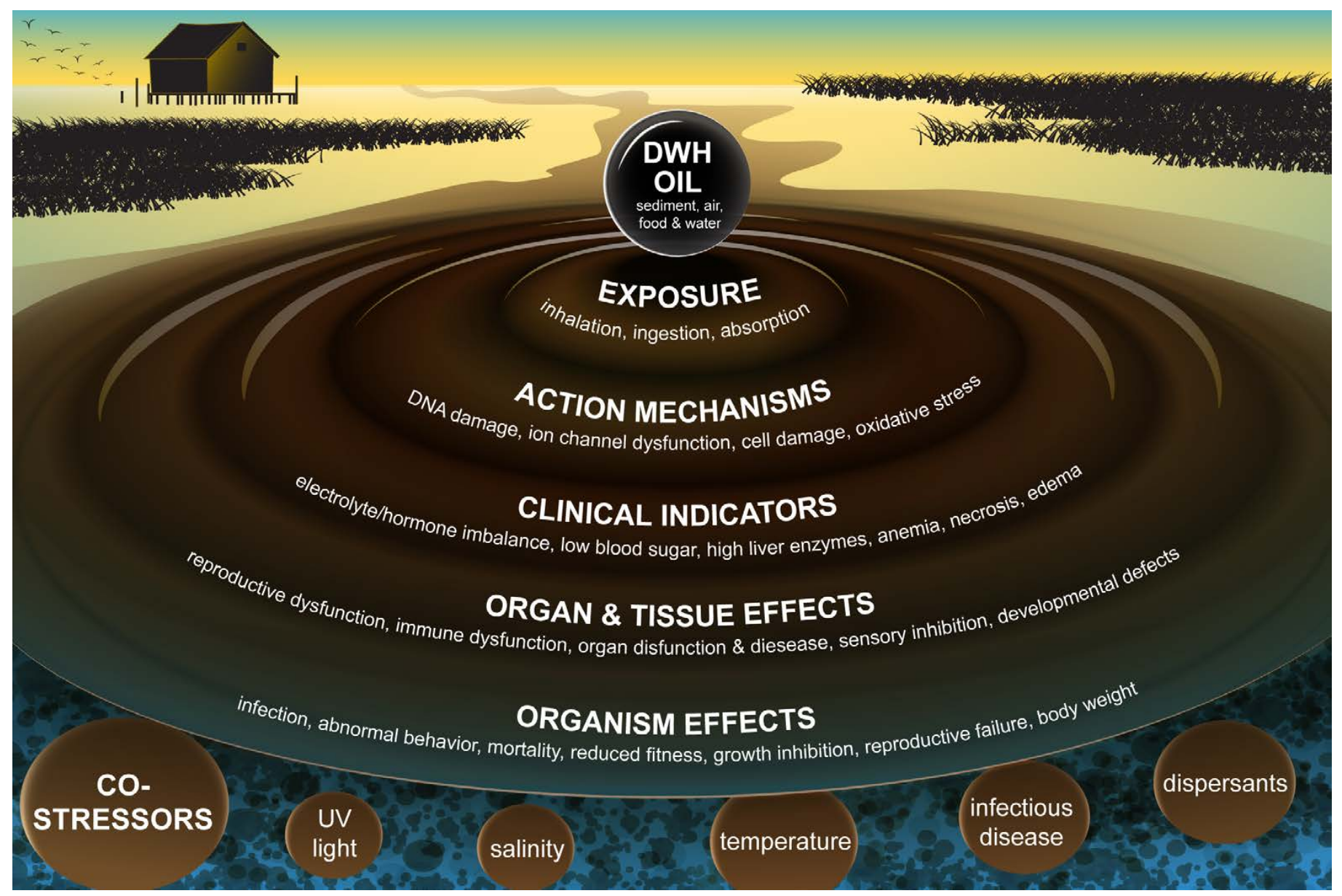

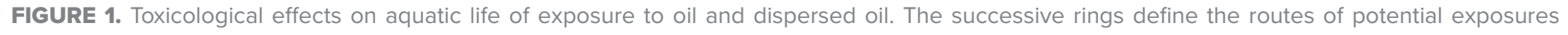

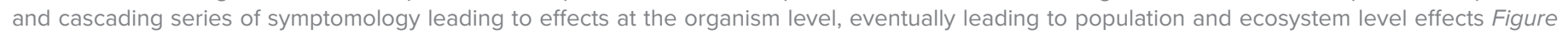
recrafted from a similar diagram in Deepwater Horizon Natural Resource Damage Trustees (2016) 
(NRC, 1985; Transportation Research Board and National Research Council, 2003; NASEM, 2020). While the fields of cellular biology and mutagenesis held promise for understanding the pathways of injury short of lethality (i.e., NRC, 1985), most studies of oil pollution up to the time of the Torrey Canyon tanker spill in 1967 were directed primarily to physicochemical aspects and associated analytical methods (see review in NRC, 1985). Toxicity studies were primarily conducted in highly artificial laboratory settings and focused on critical oil concentrations that induced lethality (Capuzzo, 1981; Boesch and Rabalais, 1987; Capuzzo et al., 1987). A number of pioneering studies developed techniques for assessing exposure of aquatic wildlife to oil constituents, and, in particular, toxic polycyclic aromatic hydrocarbons (PAHs). Working on chronic pollution effects in urban estuaries from the 1970s to the 1990s, Usha Varanasi and her colleagues at the Northwest Fisheries Science Center (NOAA) examined exposures of benthic organisms, including flatfishes, to PAHs and other toxic chemicals and determined the biochemical pathways that lead to liver cancers and symptoms of other diseases (e.g., Varanasi et al., 1979; 1987; Krahn et al., 1986; Collier and Varanasi, 1987; Stein et al., 1990). This era was also the subject of intensive oil-related toxicology research in Europe and elsewhere. Subsequent to Torrey Canyon, and particularly in response to the 1989 Exxon Valdez tanker spill (Rice et al., 1996), a variety of sublethal effects of exposure to oil and especially to PAHs were correlated with adverse effects on resource populations of salmon, birds, marine mammals, and other species (Rice et al., 1996; Peterson et al., 2003).

Discovering pathways by which exposure to PAHs induces various pathologies was aided by the finding that in the presence of various PAH compounds, the aryl hydrocarbon receptor (AhR) transcription factor is activated, inducing the expression of the cytochrome P450 1A (CYP1A) gene by binding to the AhR (for a review of the history of the discovery and use of AhR, see Okey, 2007; Stegeman et al., 2001; Incardona, 2017; and Grosell and Pasparakis, 2021). The elevated expression of the CYP1A gene is commonly measured by the presence of ethoxyresorufin-O-deethylase (EROD) activity as a biomarker of PAH exposure. While elevated EROD activity does indicate exposure, it does not, alone, indicate the effects $\mathrm{PAH}$ exposure may have; activation of gene activity does indicate that the vertebrate organism is attempting to metabolize the PAHs into more polar compounds for eventual excretion (Meador et al. 1995; Grosell and Pasparakis, 2021).

The presence of DNA adducts (chemicals binding to DNA sequences) formed subsequent to $\mathrm{PAH}$ exposure is not only indicative of the activation of the CYP1A gene but also implies alterations to the transcriptome that may or may not be harmful to the animal. With the mapping of gene sequences to their particular function (e.g., growth, wound healing, osmoregulation), it is then possible to evaluate the differential expressions of all genes (e.g., through the production of RNA sequences as DNA is replicated) to assess which are up- and down-regulated in the presence of PAHs or any xenobiotic chemical (Harrill et al., 2019). If there is a map of the gene sequences with functional annotations, it may be possible to determine which of the organism's homeostatic mechanisms may be positively or negatively affected.

By far, most of the work to date has focused on transcriptomics (changes in genome-wide gene expression) rather than on changes in the genome itself. The state of the field on transcriptomics today is to link the phenotypes (physiology and behavior) to gene expression, which permits the use of gene expression data to infer effects (Xu et al., 2016, 2017a,b; Diamante et al., 2017).

Most often, studies of pollutant effects on gene expression are conducted with "model" organisms (e.g., those species wherein the gene sequence is mapped and the relationships between specific genes and their functions are understood) such as zebrafish (Danio rerio). Subsequent to the DWH accident, a number of studies evaluated transcriptomics of oil exposure in a wide range of Gulf-specific organisms, including blue crab (Callinectes sapidus; Yednock et al., 2015), dolphinfish (Coryphaena hippurus, aka mahi-mahi; $\mathrm{Xu}$ et al., 2016), tilefish (Lopholatilus chamaeleonticeps) and red snapper (Lutjanus campechanus) (Deak, 2020), Gulf killifish (Fundulus grandis; T.I. Garcia et al., 2012; Whitehead et al., 2012; Dubansky et al., 2013), red drum (Sciaenops ocellatus; Hollenbeck et al., 2017; Xu et al., 2017b; Khursigara et al., 2017), southern flounder (Paralichthys lethostigma; Sherwood et al., 2017; Rodgers et al., 2021), and seaside sparrows (Ammodramus maritimus; Bonisoli-Alquati et al., 2020), among others. Because of the lack of appropriate a priori gene sequence information for any of these species, researchers reconstructed gene expression profiles from short sequences based on RNA using a process known as de novo assembly (akin to solving a two-billion-piece jigsaw puzzle) and differential gene expression.

While relative gene expression varied among species and experimental conditions, immune system responses and sequences involved in responses to xenobiotic exposure were commonly upregulated (Yednock et al., 2015; Deak et al., 2020; Rodgers et al., 2021), as were indicators of antioxidant production. Conversely, down-regulated functions included lipid production and expression of genes supporting reproduction (Deak, 2020) and nervous, muscular, and cardiovascular system functions (Xu et al., 2016, 2017a,b, 2021; Diamante et al., 2017). These studies have led to a better understanding of the complex array of physiological mechanisms activated or suppressed in the presence of oil pollution and provide a biochemical basis for evaluating critical functions affecting organism and population health. These studies also point to the fact that traditional biomarkers of PAH exposure may not suffi- 
ciently characterize longer-term impacts to the organism. For example, Rodgers et al. (2021) conducted chronic exposure studies over 35 days, followed by a 30-day "recovery" period. Their results showed alteration of a number of system functions, including cholesterol metabolism even 30 days post exposure, far longer than would be indicated by the presence of elevated PAH biliary metabolites or EROD activity from a single oiling event. Transcriptomic dynamics of oil-exposed organisms not only predict which individual and cross-linked genes may be differentially expressed but also generally correlate with symptomology discovered in morphological, developmental, and physiological assessments of impacts to non-model species. Below, we highlight a number of studies conducted post-DWH that show the toxicological impacts of oil exposure as related to critical functions in species that may lead to reductions in the overall fitness or survival of individuals and ultimately their populations.

In multispecies exposure trials conducted at the Mote Marine Laboratory

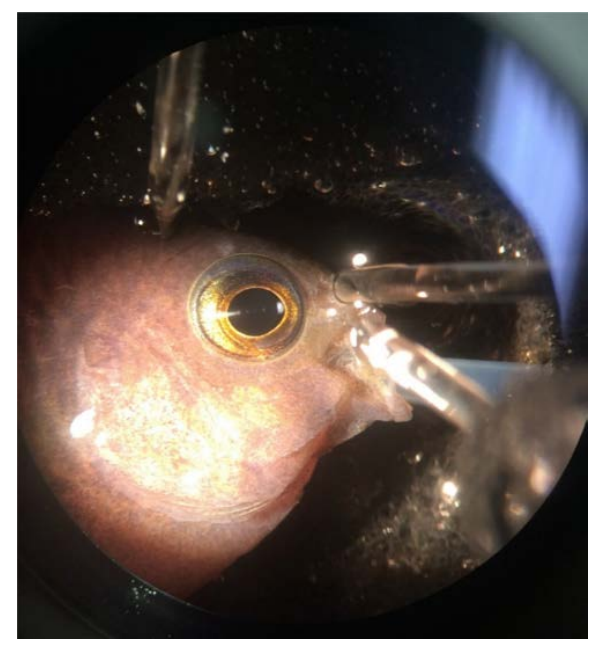

FIGURE 2. An anesthetized damselfish is prepared for recording of olfactory epithelium potentials to assess the effect of oil on olfaction. The fish is fitted with a tube passed through the mouth to perfuse the gills and ensure oxygenation, a delivery pipette to administer olfactory cues near the olfactory epithelium, a recording electrode inserted at the surface of the sensory epithelium, and a reference electrode near the skin above the eye. Photo credit: Lela S. Schlenker
post-DWH, Pulster et al. (2017) exposed red drum, Florida pompano (Trachinotus carolinus), and southern flounder to intraperitoneal injections of DWH crude. Although fishes have a high capacity for metabolizing PAHs, their ability to metabolize subsequent metabolites is poorly understood. The study documented differential responses among the species and the potential for "metabolic fatigue" through the post-exposure presence of hydroxylated metabolites. Florida pompano (a high metabolic rate pelagic species) had higher rates of biotransformation for naphthalene and phenanthrene than the other two, suggesting pompano may have lower susceptibility to adverse effects. Results for these three Gulf of Mexico species demonstrated species-specific vulnerability to adverse outcomes for fishes exposed to identical crude oils-clearly indicating that extrapolation of oil effects from model species to environmentally relevant species is fraught. Although the response was different across the three species, with Florida pompano exhibiting more rapid biotransformation, the long-term consequences of previously unstudied metabolites that may persist in fishes remains poorly understood and is a prime subject for future research. Vast sensitivity differences ( $>2$ orders of magnitude) among species exposed to water accommodated fractions (WAFs) of DWH oil have also become evident since 2010 (Pasparakis et al., 2021).

Other studies of oil exposure with non-model fish species demonstrated additional important sublethal effects. Dose-dependent growth inhibition was demonstrated in southern flounder (Brown-Peterson et al., 2015) and for larval and juvenile spotted seatrout (Cynoscion nebulosus; Brewton et al., 2013). Oil exposure can also induce tissue histopathology in livers and gills and decreased lymphocyte and granulocyte densities in southern flounder (Brown-Peterson et al., 2015), alligator gar (Atractosteus spatula; Omar-Ali et al., 2015), and menhaden (Brevoortia spp.;
Bentivegna et al., 2015).

In addition to effects noted above, a variety of studies conducted post-DWH have emphasized broader physiological, metabolic, and behavioral impacts of oil exposure on a wide range of non-model species. These effects include, among others, changes in central nervous systems (behavior), peripheral nervous systems (olfaction, vision), cardiovascular function, respiration, swimming performance, prey capture, immune response, stress response, reproduction, Aryl hydrocarbon receptor activation, and cholesterol biosynthesis.

Olfactory cues (i.e., particular smells the animal associates with some state of nature) evoke behavioral responses that are crucial to survival in fishes and other animals. Receptors, including olfactory sensor neurons, are susceptible to damage from aquatic contaminants. In WAF exposure studies to crude oil, bicolor damselfish (Stegastes partitus) did not respond to chemical alarm cues that would normally lead to predator avoidance. Hence, sublethal WAF exposure modified detection of chemical cues for up to eight days, suggesting at least short-term reduction in predator avoidance (Schlenkler et al., 2019a; Figure 2). In a similar experimental setup at the University of Miami, mahi-mahi avoided oiled water in favor of unoiled seawater, and avoidance increased in proportion to the concentration of crude oil in water. Even a short-term (24 h) oil exposure disrupted that behavior, leading to the inability of the fish to avoid oil contamination. Oil-exposed and control fish detected crude oil through an olfaction cue, although oil-exposed mahi-mahi showed no differences in physiology at the olfactory epithelium as compared to controls. Thus, observed behavioral alterations are occurring in the olfactory bulb or at higher brain centers and not at the olfactory epithelium. Results of these behavioral trials suggest that mahimahi may be able to sense and avoid oiled areas, but once exposed, fish will not seek clean water and will thus likely be contin- 
ually exposed (Schlenker et al., 2019b).

Exposure of individuals to oil can also affect schooling behavior and modify group behavior even when not all animals are similarly exposed. Armstrong et al. (2019) exposed Atlanta croaker (Micropogon undulatus) individuals to crude oil and noted that schooling behavior was disrupted with exposure to $2 \%$ oil. Exposed fish groups also showed reduced voluntary movement. Not only were individual fish affected, but individual fish that were affected disrupted group behavior. Oil exposure in fish like Atlantic croaker can have adverse effects on their behavior and might lead to reduced fitness (Armstrong et al., 2019).

Perhaps one of the most important sets of studies of behavioral responses to crude oil exposure conducted postDWH examined effects on swimming behavior, particularly of pelagic species. Swim chamber respirometry of young adult mahi-mahi demonstrated that acute exposure to a sublethal concentration of DWH crude oil elicited significant decreases in critical (14\%) and optimal (10\%) swimming speeds, a $20 \%$ reduction in maximum metabolic rate, and a $29 \%$ reduction in aerobic scope (Stieglitz et al., 2016a). Similar effects were observed for juvenile mahi-mahi exposed briefly during embryonic development (Mager et al., 2014) and for red drum (Johansen and Eshbaugh, 2017) and cobia (Nelson et al., 2016, 2017). For a pelagic predator species, these reductions in swimming performance have obvious implications for their abilities to avoid predation themselves, to capture pelagic prey, and to sustain long-distance migrations.

Digging deeper into the biochemical basis for impairment of swimming performance, Grosell and Pasparakis (2021) describe the cascade of biochemical and physiological changes that occur as a result of oil exposure in mahi-mahi (Figure 3). They noted in particular that impaired cardiac function, as a result of lower heart rate and especially stroke volume-leading to reduced cardiac output-may be the proximal cause of reduced swimming
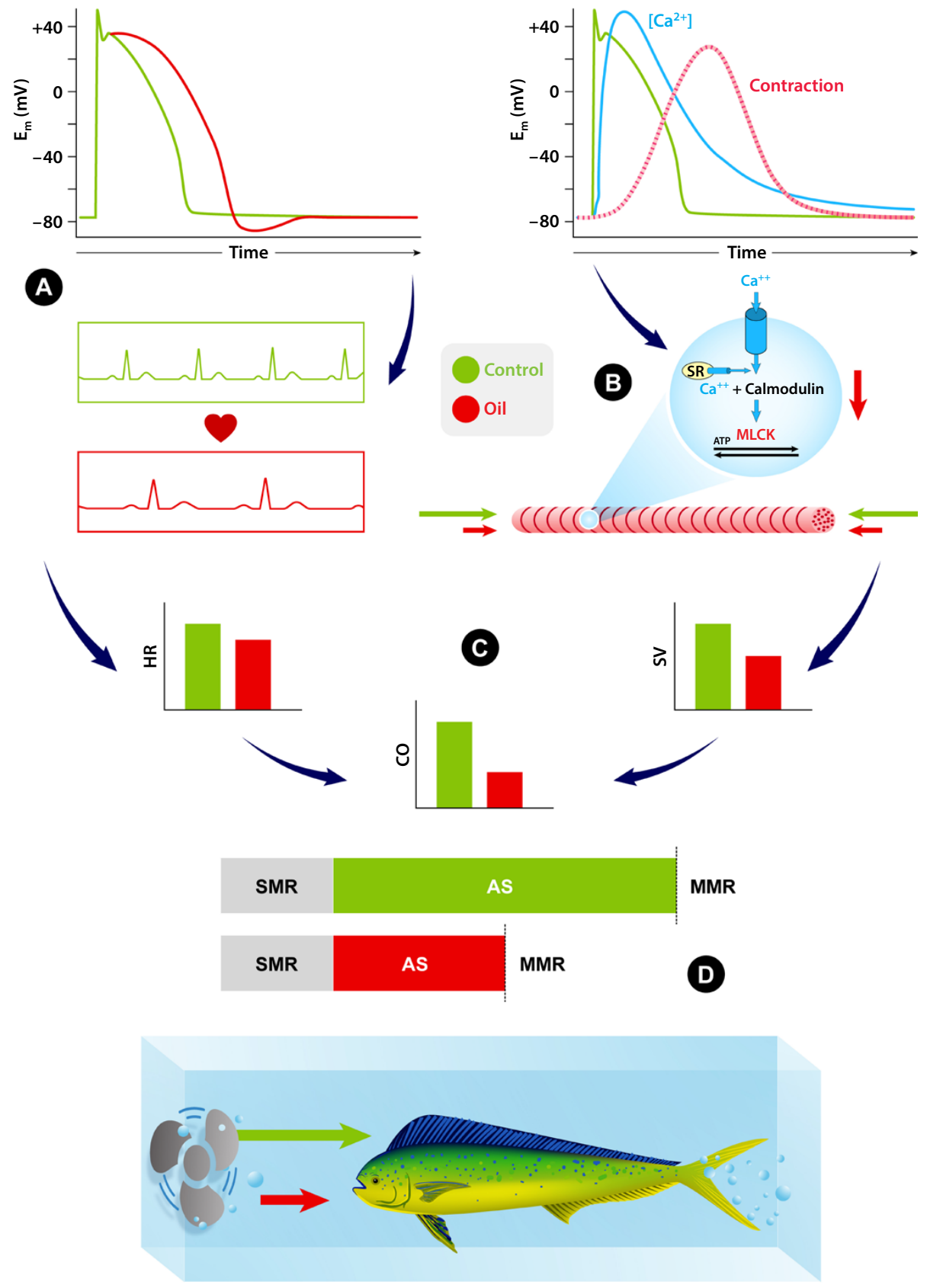

FIGURE 3. Illustration of how oil exposure (red) inhibits ion movement through the delayed rectifier potassium channel (/Kr), thereby prolonging action potentials in the heart cells of yellowfin and bluefin tunas (Brette et al., 2014). (A) Prolonged action potentials are likely the cause of the heart rate reduction observed in many oil-exposed fish. (B) Studies of isolated heart cells demonstrated decreased calcium movement (ICa) through L-type calcium channels and impaired intracellular calcium cycling in response to crude oil exposure (Brette et al., 2014, 2017). Intracellular calcium binds to myofilaments to activate heart cell contractions, and its dysregulation results in reduction of the magnitude of heart cell contraction (Heuer et al., 2019); this explains decreased stroke volume, that is, the amount of blood leaving the heart following each contraction (Nelson et al., 2016; Perrichon et al., 2018). (C) Reductions in maximal heart rate and decreased stroke volume combine to result in impaired heart function, illustrated by reductions in the total amount of blood pumped by the heart (cardiac output). (D) Decreased cardiac output limits oxygen delivery in oilexposed fish, which results in a reduced maximum metabolic rate, as observed in many studies (Thomas and Rice, 1987; Mager et al., 2014; Stieglitz et al., 2016b; Johansen and Esbaugh, 2017). Decreased maximal metabolic rate is likely responsible for impaired swimming abilities, such as reductions in maximum sustained swim speed (Ucrit), recorded in a number of oil-exposed fish. $E_{\mathrm{m}}=$ membrane potential. MLCK = myosin light chain kinase. $\mathrm{SR}=$ sarcoplasmic reticulum. From Grosell and Pasparakis (2021) 
performance. In addition, cholesterol biosynthesis, nervous system function, stress responses, osmoregulatory function, and acid-base balance processes all were disrupted following exposure to oil. Depletion of cholesterol may be a significant contributor to impacts on cardiac, neuronal, and synaptic function as well as reduced cortisol production and release. Furthermore, impairment of intracellular calcium regulation, critical for muscle contraction and regulation of heart rhythms, may be related to cholesterol depletion in oil-exposed fish (Grosell and Pasparakas, 2021).

Defects in cardiac function and cardiac abnormalities appear to be common responses with fish embryos and larvae exposed to concentrations of PAHs between $1 \mu \mathrm{g} \mathrm{L}^{-1}$ and $15 \mu \mathrm{g} \mathrm{L}^{-1}$ (i.e., in bluefin tuna, Thunnus thynnus; yellowfin tuna, Thunnus albacares; and amberjack; Incardona et al., 2014) or between $1.2 \mu \mathrm{g} \mathrm{L}^{-1}$ and $30 \mu \mathrm{g} \mathrm{L}^{-1}$ (i.e., mahi-mahi eggs and larvae, which also exhibited decreased swimming performance). Oil exposure can cause pericardial edema (fluid buildup in the sac enclosing the heart) in yellowfin and bluefin tuna and mahi-mahi embryos, with decreased heart rate and atrial contractility resulting (Incardona et al., 2014; Esbaugh et al., 2016). Cobia exposed for 24 hours to two ecologically relevant concentrations of dissolved PAHs, similar to mahimahi, exhibited reduced cardiac function as measured through cardiac power output (pumping). This effect was mitigated through additional exposure to adrenergenic stimulation that may serve as a compensatory response (Cox et al., 2017; Nelson et al., 2017).

Embryonic stages of mahi-mahi displayed acute toxicity at concentrations as low as $8.7 \mu \mathrm{g} \mathrm{L}^{-1}$ PAHs (Esbaugh et al., 2016). Other morphological deformities such as fin fold damage, craniofacial malformations, and spinal curvatures have been observed during $48 \mathrm{~h}$ exposures to oil concentrations of $1.2 \mu \mathrm{g} \mathrm{L} \mathrm{L}^{-1}$ for embryos and $30 \mu \mathrm{g} \mathrm{L}^{-1}$ PAHs for larvae (Grosell and Pasparakis, 2021; Mager et al., 2014).
Impacts of oil exposure were not limited to vertebrates, and a variety of toxicology studies with non-model invertebrate species resulted in a range of toxicological effects. Sublethal exposure to realistic concentrations of crude oil can significantly decrease copepod (Acartia tonsa) escape swimming performance (Almeda et al., 2014a, 2016). This has implications for trophic transfer of hydrocarbons in marine food webs. Similarly, the routine swimming speeds of barnacle and copepod larvae were found to be significantly reduced when the organisms were exposed to realistic concentrations of crude oil and crude oil with dispersant; however, no change was observed in dispersant-only treatments (Almeda et al., 2014b). For planktonic copepods (Acartia tonsa, Temora turbinate, and Pseudodiaptomus pelagicus), low concentrations of dispersed crude oil $\left(1 \mathrm{~mL} \mathrm{~L}^{-1}\right)$ caused a significant reduction in survival, growth, and swimming activity of copepod nauplii after $48 \mathrm{~h}$ of exposure (Almeda et al., 2016). UVB radiation increased toxicity of dispersed crude oil by 1.3-3.8 times (Almeda et al., 2016). In eastern oyster early life history stages, a larger proportion of veligers were inactive following WAF and CEWAF (i.e., WAF enhanced with chemical dispersants) exposure as compared to controls; the effect was greater for pediveligers, and pediveliger settlement at the highest concentration CEWAF treatment decreased by $50 \%$ compared to controls (S.M. Garcia et al., 2020). Thus, pediveligers may be particularly vulnerable to oil exposure. Significant reduction in clearance rates for adult oysters persisted 33 days after acute exposure to CEWAF (S.M. Garcia et al., 2020). For shallow-water corals (Porites astreoides and Montastraea faveolata) exposed to WAF, CEWAF, and dispersants, settlement and survival of larvae decreased with increasing concentrations, although the degree of the response varied by species (Goodbody-Gringley et al., 2013). Shallow-water corals exhibited significant changes in gene expression. Upregulation of cellular machinery associated with detoxification and depuration occurred at concentrations four to eight times lower than that for physical effects (N.R. Turner, 2020).

While all of the laboratory studies summarized above have implications for non-model populations in the wild, quantifying the effects at population and ecosystem levels (e.g., Wiesenburg et al., 2021, in this issue) requires that a sufficient proportion of the population be exposed to oil and that this exposure can be detected despite the intermittent and localized nature of field-based sampling. Given that oil concentrations during DWH were not uniform over the extensive footprint of the spill, nor consistent in time (Deepwater Horizon Natural Resource Damage Assessment Trustees, 2016), it is a particular sampling challenge to document the consequences of the spill to population outcomes. As prespill baselines of oil contamination were rarely collected prior to $\mathrm{DWH}$, characterizing the degree and persistence of oil pollution in biota resulting from this particular spill was challenging owing to the range of other sources of oil pollution in the Gulf of Mexico (Transportation Research Board and National Research Council, 2003). Nevertheless, ongoing field-based sampling programs supported by GoMRI, some results of which are described below, generally comport well with parallel laboratory studies described above.

\section{Monitoring Toxicological \\ Impacts in the Field}

Field-level sampling conducted postDWH also provides important insights into toxicological responses of populations to elevated PAH exposure. Determining which individuals in a population have been exposed at what concentrations to a particular spill is extremely challenging. As noted above, the lack of pre-spill baselines of contaminant exposure often impedes the attribution of cause and effect, as does the presence of multiple simultaneous sources of contaminants such as PAHs. For example, 
as reported in Transportation Research Board and National Research Council (2003), a number of natural and anthropogenic sources of petroleum contribute to a diverse oil pollution budget in the Gulf of Mexico. Two important pieces of information, however, can narrow source attribution to a particular event. If, as was the case for DWH, the concentrations of PAHs in animal tissues are elevated in the region affected by the spill as compared with other areas within the ecoregion (Gulf of Mexico) that are not affected by the spill, this presents strong circumstantial support for considering a particular source, especially if the volume is large or persistent over time. Secondly, if, in postevent monitoring of the affected region, concentrations decline over time, this too presents strong evidence as to source, at least in the circumstances where residual oil is biologically unavailable to the species in question.

Field-based studies demonstrated that these two conditions were met; in addition, coincident post-DWH sampling of animal tissues revealed associated symptomology consistent with toxic exposures. Murawski et al. (2014) found elevated frequencies of external skin lesions (Figure 4) and PAH concentrations in liver and bile metabolites from red snapper and other species in 2011 as compared to those sampled in 2012. Subsequently, Snyder et al. (2015) and Pulster et al. (2020a,b,c,d) demonstrated further declines in PAHs and associated metabolites in red snapper and in king snake eel (Ophichthus rex) in continental shelf areas affected by DWH. They also expanded the number of species examined and, importantly, showed strong contrasting concentrations of PAHs between the northern Gulf of Mexico where DWH occurred and the rest of the Gulf (Figure 5), as did Snyder et al. (2020) for tilefish. Similarly, PAH concentrations were inversely correlated with the frequency of skin lesions (Snyder et al., 2015). Snyder et al. (2019) found increasing $\mathrm{PAH}$ concentrations in bile but not liver from tilefish, a benthic species, sam- pled during 2012-2017 in the northern Gulf of Mexico, which correlated inversely with body condition (weight for a given length) and percent liver lipid. Histopathological evaluations also indicated a decline in liver lipid storage and a coincident increase in hepatic glycogen storage (Snyder, 2020). Together, these findings suggest an association between chronic and increasing $\mathrm{PAH}$ exposure, altered energy storage, and reduced body condition, all of which influence the overall fitness of the individuals and, by inference, the population. The seem-

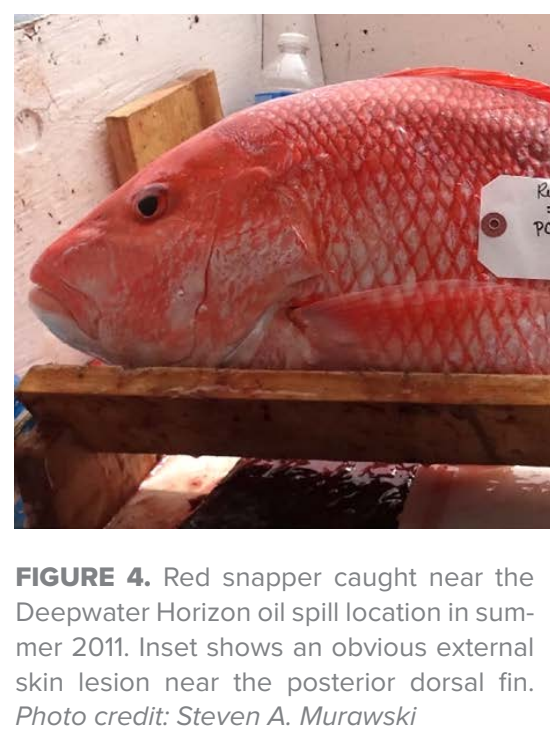

Photo credit: Steven A. Murawski

FIGURE 5. Contour map of biliary naphthalene metabolite concentrations in fishes sampled throughout the continental shelves of the Gulf of Mexico, 2011-2018. Data show high concentrations in the region impacted by the Deepwater Horizon oil spill. From Pulster et al. (2020b)

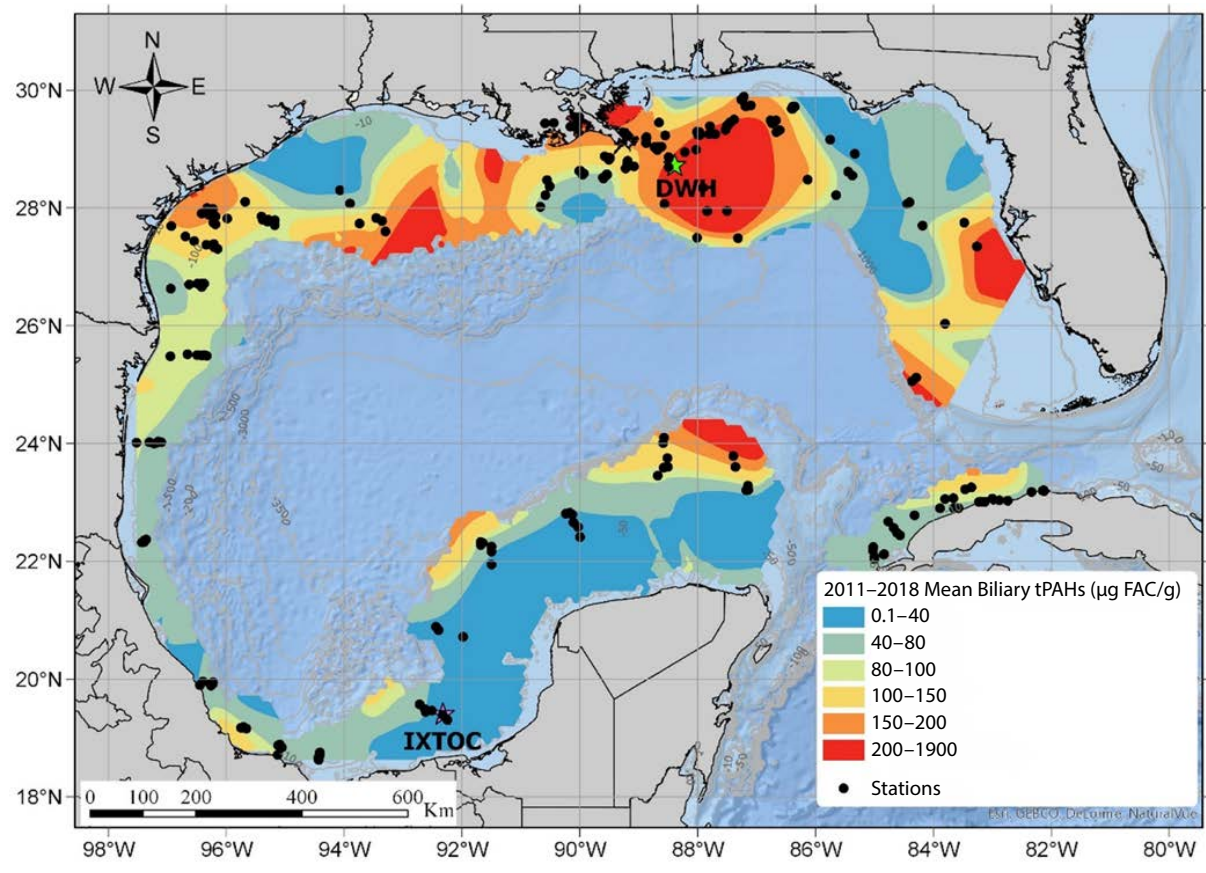


ingly contradictory increasing trend in oil contamination for tilefish probably is a result of their burrowing into oil-contaminated sediments. Pulster et al. (2021) likewise correlated a suite of liver pathologies with PAH exposure. Importantly, in a series of laboratory experiments, Bayha et al. (2017) demonstrated that exposure to oil followed by a bacterial challenge with Vibrio anguillarum induced downregulation in immune response of southern flounder and ultimately the appearance of external skin lesions and other morphological symptoms consistent with bacterial infection, whereas test animals exposed only to the bacteria challenge exhibited none of these effects. These experiments thus confirmed the immunosuppressive mechanism likely responsible for the positive correlation between $\mathrm{PAH}$ exposure and skin lesion frequency as determined from field-sampled fishes (Murawski et al., 2014; Pulster et al., 2020c) and are consistent with a wider body of research elsewhere demonstrating that external skin lesions are correlated with PAH exposure (e.g., Myers et al., 1994).

Once the DWH oil was transported to coastal ecosystems, there were a variety of impacts on inshore species ranging from none to significant (Fodrie et al., 2014; Able et al., 2015; Powers et al., 2017; Murawski et al., 2021). Gulf killifish initially showed linkages between gene expression and gill immunohistochemistry and oil exposure within the first four months of marsh oiling, with CYP1A protein expression and gill morphological changes being symptomatic of oil exposure (Whitehead et al., 2012). Killifish larvae exposed to oiled sediments had poorer hatching success as compared with controls, and larvae showed differential gene expression in both gill and especially liver tissues (Dubansky et al., 2013). Because elevated oil concentrations in marsh sediments persisted at concentrations an order of magnitude over background levels in Louisiana marshes even eight years postDWH (Turner et al., 2019), there is con- cern about long-term effects of the spill in these areas (Dubansky et al., 2013).

In marshes subjected to high levels of oiling from DWH, losses of the marsh grass Spartina alterniflora, particularly at marsh edges, were significant (Lin and Mendelssohn, 2012; Fleeger et al., 2015, 2018, 2019, 2020; Lin et al., 2016; Deis et al., 2017). Some infauna in oiled marshes denuded of vegetation recovered to densities equivalent to unoiled reference sites in about a year's time after the regrowth of Spartina began (Fleeger et al., 2015). However, epigenetic differentiation in response to oil contamination was not detected, probably due to the high levels of genetic variability inherent in the species and the fact that seed dispersal is facilitated by winds (Robertson et al., 2017). Similarly, recruitment from non-oiled patches may be responsible for the lack of long-term effects of oiling on marsh minnow assemblages (e.g., Able et al., 2015).

During and subsequent to DWH, ciliate zooplankton-major grazers of phytoplankton-were negatively affected by exposure to oil/dispersants, whereas bloom-forming dinoflagellates increased in abundance (Almeda et al., 2018). The results of this field investigation imply removal of key grazers due to oil and dispersant may disrupt predator-prey controls ("top-down controls") that, under normal conditions, would suppress blooms of toxic dinoflagellates. In subsequent laboratory studies using bacteria isolated from oil contaminated sediments from the 2014 Galveston "Y" oil spill (Park et al., 2020), the oil-degrading bacterial isolates significantly stimulated growth of dinoflagellates through the release of growth-promoting substances. Thus, impacts on low trophic levels occur not only through trophic "cascades" (e.g., Almeda et al., 2018) but also through the co-production of phytoplankton "growth factors" (Park et al., 2020), both of which have implications for natural ecosystem dynamics and human health.

The effects of oil and dispersants on coastal mesozooplankton (plankton in the size range of $0.2-20 \mathrm{~mm}$ ) were evaluated in the field and in laboratory-based experimentation. Mortality of mesozooplankton increased with increasing oil concentration (the median lethal concentration was $32.4 \mathrm{~mL} \mathrm{~L}^{-1}$ ). Dispersants applied at a 1:20 ratio increased toxicity by 0.3 to 3.4 times. Bioaccumulation of PAHs documented in the mesoplankton community increased by $35 \%$. The conclusion was that oil spills negatively impact mesozooplankton (Almeda et al., 2014a) and also ctenophores (Peiffer and Cohen, 2015), and this effect increases with the use of chemical dispersants and coincident exposure to UV radiation.

For some species groups affected by the spill, a variety of logistical challenges and ethical concerns prevent direct exposure trials in laboratory settings. Such is the case for marine mammals impacted by DWH. As a result, a combination of nonlethal field sampling and laboratory studies of model species and cell lines of affected species, and comparisons with otherwise healthy animals in managed settings (e.g., Figure 6), was conducted to address priority questions related to health effects of oil exposure in common bottlenose dolphins (Tursiops truncates) in the northern Gulf of Mexico inshore habitats. Dolphins living within the oil spill footprint sustained a high reproductive failure rate. Capture-release health assessments focusing on fetal, placental, and maternal health of Barataria Bay dolphins, and photo-ID field studies focused on reproductive outcomes, documented a continuation of the low reproductive success rate of only $20 \%$ within the oil spill footprint. The success rate remained fairly consistent at $\sim 20 \%$ from 2011 onward (Smith et al., 2020).

Chronic maternal illness in the aftermath of the DWH oil spill is the likely cause of reproductive failure. Normal progression of fetal development in utero (Barratclough et al., 2020; Ivančić et al., 2020) and retrospective examination of pregnancies with known failed outcomes have enabled several hypotheses as to the 
potential mechanisms of pregnancy failure, with maternal illness standing out unequivocally as the most important predictor for pregnancy complications (Smith et al., 2020). Various data were integrated with the complete veterinary case history for each dam (female) and the resulting fetal and placental histopathology findings to elucidate maternal, placental, and fetal predictors of pregnancy failure. Exhaustive analyses have proven pivotal for understanding of reproductive failure in dolphins and have provided a mechanistic model with which to analyze and interpret wild dolphin cases, even if only a single exam is available (Gomez et al., 2020).

Additional health assessments of Barataria Bay dolphins included pulmonary ultrasound evaluations, utilizing a standardized technique developed with managed dolphins (Figure 6), which have informed the comprehensive analysis. The prevalence of moderate to severe lung disease in dolphins that were alive at the time of the DWH spill and presumably exposed to oiling in Barataria Bay, remained elevated in comparison to dolphins outside the oil spill footprint (Smith et al., 2017, 2021). Lungs were scored as moderate to severe in $35 \%$ of dolphins in 2017 and 54\% in 2018, significantly higher than the $7 \%$ in reference-site dolphins (Sarasota Bay, Florida). Overall, the prevalence of pulmonary disease is contributing to the overall poor maternal health of Barataria Bay dolphins, which in turn is contributing to the sustained high reproductive failure rate.

Based on the medical data generated, scientists do not expect the maternal reproductive failure rate to improve until the overall health of reproductive females in Barataria Bay improves. With the sustained low reproductive success rate in Barataria Bay, it is essential that maternal health be continuously monitored and addressed.

Cardiac assessment techniques never before applied in wild dolphins, including auscultation, echocardiography, and electrocardiography, were developed and per-

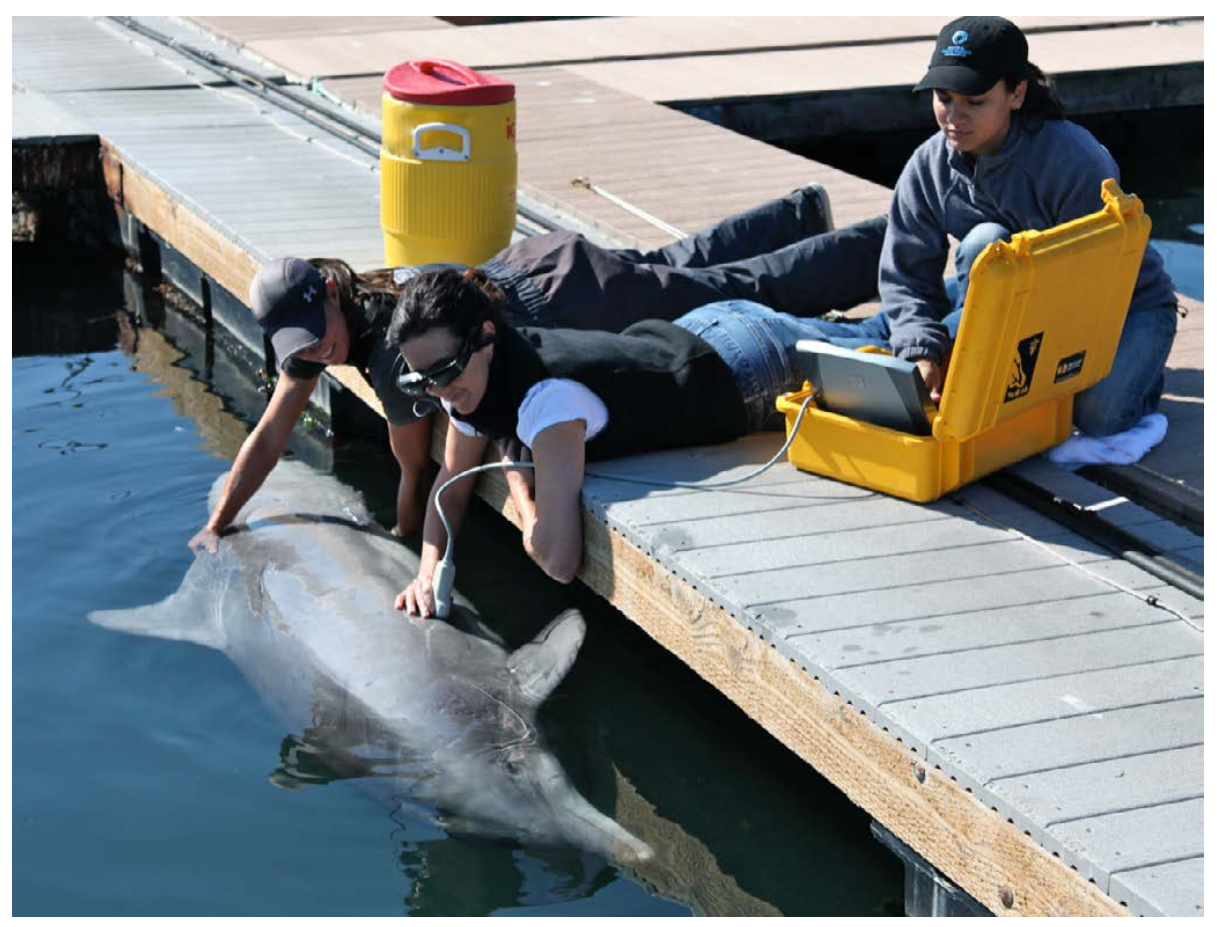

FIGURE 6. From left, Megan Tormey, Cynthia Smith, and Veronica Cendejas conduct a voluntary ultrasound examination of a Navy dolphin in San Diego Bay, California, using a heads-up display (virtual reality goggles) to view the diagnostic ultrasound image in real time. Photo courtesy of the US Navy

formed on dolphins from both Barataria Bay and the Sarasota Bay comparison site (Linnehan et al., 2020; Barbara Linnehan, National Marine Mammal Foundation, pers. comm., 2021). Taken together with stranding studies, these findings suggest that there may be cardiac effects of oil exposure in dolphins either via direct effects to the heart that lead to morphometric abnormalities/lesions or via damage to the lung and secondary heart effects (Barbara Linnehan, pers. comm., 2021). Immunological studies demonstrated a variety of dysregulated immune system components, including the proportions and function of regulatory $\mathrm{T}$ cells, cytokine patterns, and inflammation markers. The weight of evidence for an association with oil exposure was enhanced by experimental laboratory studies that exposed mice to DWH oil and in vitro dolphin cells to DWH oil (De Guise et al., 2021).

Understanding toxicological impacts on deep-sea fauna presents particular challenges owing to the difficulty of sampling them, the inability to husband them in the laboratory for experimentation, and the general lack of detailed life history, behavioral, and baseline toxicological data (Sutton et al., 2020). Nevertheless, the mesopelagic is a highly diverse realm (e.g., over half of the known fish species in the Gulf of Mexico occupy these water column strata; Figure 7), and a significant quantity of DWH oil and its gas components dissolved in subsurface habitats (Deepwater Horizon Natural Resource Damage Trustees, 2016). Novel trawling activities in the mesopelagic areas of the Gulf of Mexico affected by DWH detected significant increases in PAH content postDWH in mesopelagic fishes (Romero at al., 2018) and in squids (Romero et al., 2020). In the case of deepwater squids, increases in PAHs in squid mantle tissues were accompanied by a significant decline in percent lipid, similar to patterns found in tilefish (a deep-dwelling fish found along the outer continental shelf; Snyder et al., 2020). The exposure to toxic effects of oil appeared to be more prolonged in these organisms than in shallow-water biotic analogs (Romero et al., 2020). The significant and ongoing 


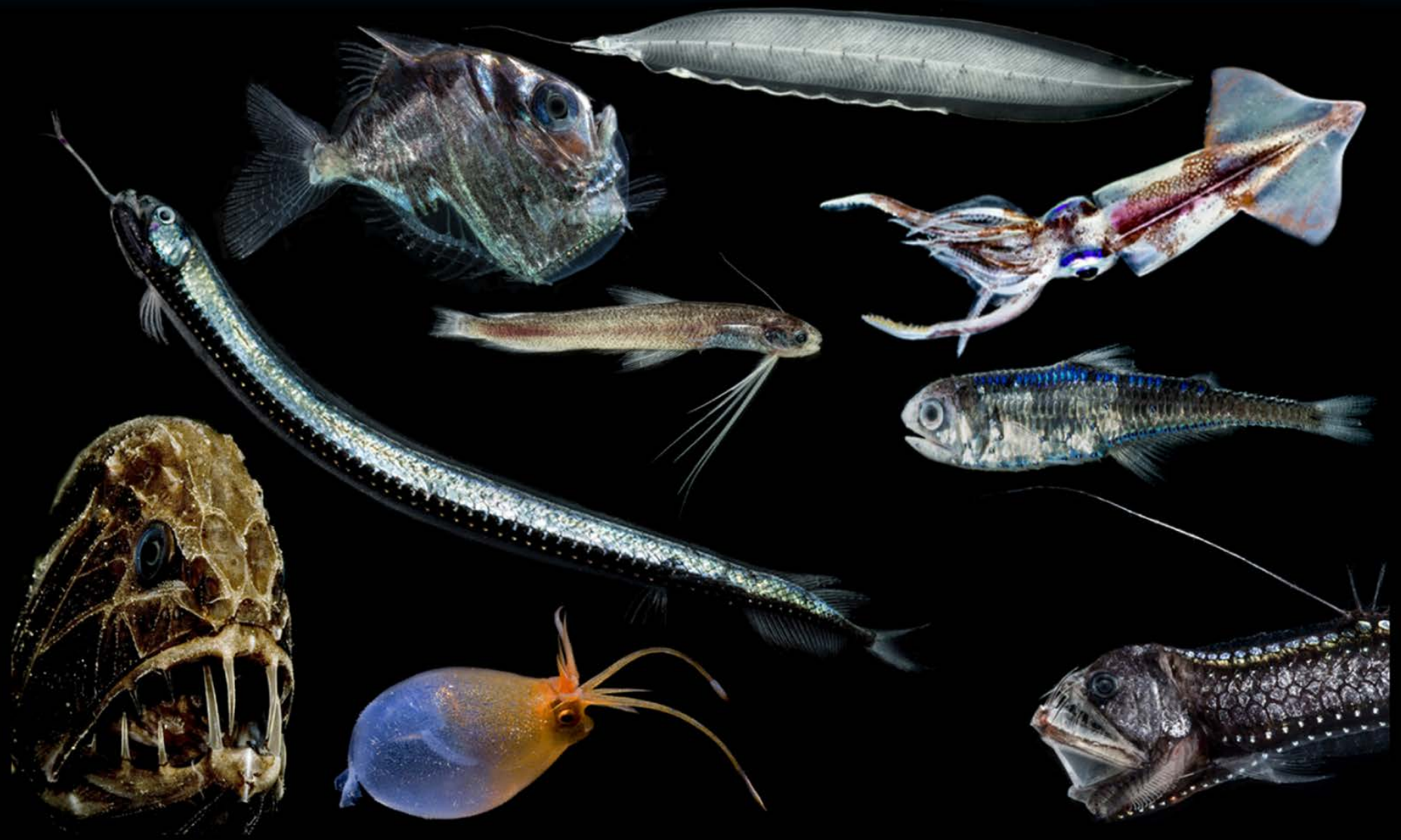

FIGURE 7. Examples of mesopelagic fishes and squids captured by a MOCNESS (multiple opening and closing net environmental sampling system) in the Gulf of Mexico during post-Deepwater Horizon field activities, 2010-2018 (Sutton et al., 2020). The small fish pictured in the center is an antenna codlet (Bregmaceros atlanticus). Identifications for the other images, clockwise from lower left, are fangtooth (Anoplogaster cornuta), scaly dragonfish (Stomias affinis), diaphanous hatchetfish (Sternoptyx diaphana), eel leptocephalus larva (llyophinae sp. D3), clubhook squid (Onychoteuthis banksii), Cocco's lanternfish (Gonichthys cocco), Dana viperfish (Chauliodus danae), glass squid (Cranchia scabra). Images $\odot$ Dante Fenolio

abundance decline across all major invertebrate and fish deepwater taxa (Sutton et al. 2020) that has coincided with the DWH spill and is coincident with the discovery of elevated PAH levels and other biochemical changes provides strong circumstantial evidence of a toxicological triggering event. Changes in the mesopelagic prey base were accompanied by shifts in the distribution of major marine mammal predators, including whales and dolphins (Fraiser, 2020; Fraiser et al., 2020), although seasonal movements in species such as sperm whales (Physeter macrocephalus) were apparent (Morano et al., 2020). While direct oil contamination may have elicited many of the toxicological impacts seen in other species, disruption of chemosensory abilities may be particularly important as an outcome for deep-sea biota. Many mesopelagic fish species have highly developed brain regions involved in chemosensing, olfaction, and light reception (Wagner, 2001). Chemical (and light) sensory signaling in mesopelagic fishes and invertebrates may be particularly important in their reproduction, given low light levels and low animal densities in this large ecosystem (Zimmer and Butman, 2000). As noted above, fishes are able to detect and discriminate oil contamination, and the effects of exposure may be long lasting. Although not studied in detail, disruption of chemosensory capabilities may be a mechanism at least partially responsible for the significant decline in these species post-DWH.

\section{A PATH FORWARD FOR BIOLOCICAL EFFECTS}

\section{ASSESSMENT OF OIL SPILLS}

Few studies of the effects of oil spills track the fate and toxicity of spilled oil over timescales sufficient to capture the totality of weathering processes to near extinction. An exception has been the over 40-year study of the effects of the 1969 \#2 fuel oil spill from the barge Florida off West Falmouth, Massachusetts (Cape Cod). Because of its location near the Woods Hole Oceanographic Institution and oil spill expertise and resources located there, the grounded oil in the West Falmouth salt marsh has been periodically monitored and its effects on biota analyzed, resulting in a number of seminal publications (Burns 
and Teal, 1979; Sanders et al., 1980; Teal et al., 1992; Reddy et al., 2002; Peacock et al., 2005). One of the most illuminating findings of this longitudinal study was the persistence of oil when it eventually became buried in marsh sediments to a depth where anoxic conditions exist. Similarly, prospecting for residual oil in low-energy environments, including coastal mangrove forests of the western Yucatán, revealed incompletely weathered remnants likely from the 1979-1980 Ixtoc 1 oil spill off Mexico (Radović et al., 2020). More recently, oil from the Deepwater Horizon was found to be similarly persistent in marsh sediments over eight years post-spill (Turner et al., 2019). Thus, the full impacts of spills on organisms and ecosystems cannot be completely characterized from short-duration studies following spills. In the case of significant oil spills, provisions for periodic (decadal-scale) assessments of oil persistence and ongoing impacts are therefore imperative.

This paper highlights some important developments in understanding the sublethal but nevertheless significant impacts on biota from the DWH oil spill. The advent of access to relatively powerful and cost-effective procedures and methods for evaluating changes at genomic, transcriptomic, and subcellular scales (Figure 1) has allowed a more complete understanding of the effects xenobiotic exposures may have on individuals, and by extrapolation to field data, on populations of marine life. Several important points, however, must be emphasized. First, the impacts of such a large and prolonged spill to long-lived populations and their communities have not ceased. Large reservoirs of partially weathered $\mathrm{DWH}$ oil remain in the environment (i.e., in the deep sea and in marshes; Turner et al., 2019; Schwing et al., 2020), and it may take decades to a century or more for the residual oil to decompose or be land-filled and essentially rendered biologically inert. What are the long-term consequences of these residual oil pools? Second, what kind of genetic legacy, if at all, does DWH leave? There have been very few studies of the impacts on the heritability of genetic alterations induced by prolonged and widespread oil pollution (e.g., White et al., 1999; Bautista and Burggren, 2019). While some experiments with $F_{1}$ and $F_{2}$ generations were attempted, results have so far been equivocal. Grosell and Pasparakis (2021) note that much of the biota of the northern Gulf of Mexico may have become adapted to the presence of naturally occurring and anthropogenically derived hydrocarbons, and thus the consequences of chronic pollution originating from the DWH reservoirs may be partially mitigated. They caution, however, that studies have shown that offspring from oilpolluted parents may be more susceptible to other stressors and have relatively poorer survival rates. If heritable but consequentially negative traits result from DWH pollution, the long-term prognosis for affected populations may be altered. If, however, heritable traits result in subsequent generations being more resilient to pollution, the legacy of DWH may in fact be a more positive one. Study of short-lived species ( $<4$ years), such as the Atlantic killifish (Fundulus heteroclitus) commonly found in polluted urban estuaries, have provided evidence of rapidly evolved tolerances to environmental toxicants and anthropogenic pollution (Whitehead et al., 2017). However, evolutionary adaptations are rarely successful because they tend not to occur without physiological costs (e.g., reproductive fitness). In some species (e.g., longer-lived) or large populations, tolerance adaptations may not evolve fast enough to keep pace with their rapidly changing environment, and thus are not advantageous. Clearly, this is unfinished but important business to resolve.

Apart from conducting additional work on the heritability of pollutionrelated effects, a number of other highpriority research topics related to the toxicology of oil spills include:

- Continuing research on molecular and physiological cascades that occur during and after exposures and how they affect homeostatic mechanisms of the individual and fitness of populations.

- Collecting and analyzing routine toxicological baselines (including chemical analysis, study of sublethal biomarkers of contamination, and pathology assessments) for non-model species occurring in regions where significant oil and gas development and production are located.

- Developing rapid molecular tools and testing procedures to determine exposure, that is, greater use of semipermeable membrane devices (SPMDs), both to collect baseline contaminant data and to monitor pollution during and after spills. SPMDs are passive devices that may indicate the cumulative relative oil exposure within a parcel of water and thus can be a useful tool for determining the spatial mosaic of exposure concentrations. However, since they are inanimate objects, exposure potential is not mediated by physiology (e.g., ability to metabolize pollutants vs. accumulate them).

- Refining models for extrapolating laboratory results to the field, especially given the mosaic of differing contaminant concentrations (below, at, or exceeding critical contaminant concentrations resulting in lethal or sublethal effects) occurring in real spills.

- Updating and standardizing the protocols for the manufacture, use, and interpretation of WAFS and CEWAFs for exposure studies.

- Generating annotated gene maps for environmentally relevant, non-model organisms likely to be affected in oil spill-prone locations (e.g., Gulf of Mexico).

- Identifying and evaluating the toxicity of $\mathrm{PAH}$ metabolites and their metabolites.

- Evaluating sensory pathways in mesopelagic species and effects that oil pollution may cause in disrupting such mechanisms. @ 


\section{REFERENCES}

Able, K.W., P.C. López-Duarte, F.J. Fodrie, O.P. Jensen, C.W. Martin, B.J. Roberts, J. Valenti, K. O'Connor, and S.C. Halbert. 2015. Fish assemblages in Louisiana salt marshes: Effects of the Macondo oil spill. Estuaries and Coasts 38:1,385-1,398, https://doi.org/10.1007/s12237-014-9890-6.

Almeda, R., S. Baca, C. Hyatt, and E.J. Buskey. 2014a. Ingestion and sublethal effects of physically and chemically dispersed crude oil on marine planktonic copepods. Ecotoxicology 23:988-1,003, https://doi.org/10.1007/s10646-014-1242-6.

Alameda, R., S. Bona, C. Foster, and E.J. Buskey. 2014b. Dispersant Corexit 9500A and chemically dispersed crude oil decreases the growth rates of meroplanktonic barnacle nauplii (Amphibalanus improvisus) and tornaria larvae (Schizocardium sp.). Marine Environmental Research 99:212e217, https://doi.org/10.1016/j.marenvres.2014.06.007.

Almeda, R., T.E. Harvey, T.L. Connelly, S. Baca, and E.J. Buskey. 2016. Influence of UVB radiation on the lethal and sublethal toxicity of dispersed crude oil to planktonic copepod nauplii. Chemosphere 152:446-458, https://doi.org/ 10.1016/j.chemosphere.2016.02.129.

Almeda, R., S. Cosgrove, and E.J. Buskey. 2018. Oil spills and dispersants can cause the initiation of potentially harmful dinoflagellate blooms ("red tides"). Environmental Science \& Technology 52:5,718-5,724, https://doi.org/10.1021/ acs.est.8b00335.

Armstrong, T., A.J. Khursigara, S.S. Killen, H. Fearnley, K.J. Parsons, and A.J. Esbaugh. 2019. Oil exposure alters social group cohesion in fish. Scientific Reports 9:1350, https://doi.org/10.1038/ s41598-019-49994-1.

Barratclough, A., F.M. Gomez. J.S. Morey, A. Deming, C. Parry, J.M. Meegan, K.P. Carlin, L.H. Schwacke, S.K. Venn-Watson, E.D. Jensen, and C.R. Smith. 2020. Pregnancy profiles in the common bottlenose dolphin (Tursiops truncatus): Clinical biochemical and hematological variations during healthy gestation and a successful outcome. Theriogenology 142:92-103, https://doi.org/ 10.1016/j.theriogenology.2019.09.028.

Barron, M.G., S.C. Chiasson, and A.C. Bejarano. 2020. Ecotoxicology of deep ocean spills. Pp. 466-478 in Deep Oil Spills. S.A. Murawski, C.H. Ainsworth, S. Gilbert, D.J. Hollander, C.B. Paris, M. Schlüter, and D.L. Wetzel, eds, Springer Nature, https://doi.org/10.1007/978-3-030-11605-7.

Bautista, N.M., and W.W. Burggren. 2019. Parental stressor exposure simultaneously conveys both adaptive and maladaptive larval phenotypes through epigenetic inheritance in the zebrafish (Danio rerio). Journal of Experimental Biology 222:jeb208918, https://doi.org/10.1242/ jeb.208918.

Bayha, K.M., N. Ortell, C.N. Ryan, K.J. Griffitt, M. Krasnec, J. Sena, T. Ramaraj, R. Takeshita, G.D. Mayer, F. Schilkey, and R.J. Griffitt. 2017. Crude oil impairs immune function and increases susceptibility to pathogenic bacteria in southern flounder. PLOS ONE 12:e0176559, https://doi.org/10.1371/ journal.pone.0176559.

Bejarano, A.C., and M.G. Barron. 2014. Development and practical application of petroleum and dispersant interspecies correlation models for aquatic species. Environmental Science \& Technology 48:4,564-4,572, https://doi.org/10.1021/ es500649v.

Bejarano, A.C., J.R. Clark, and G.M. Coelho. 2014. Issues and challenges with oil toxicity data and implications for their use in decision making: A quantitative review. Environmental Toxicology and Chemistry 33:732-742, https://doi.org/10.1002/ etc. 2501 .
Bentivegna, C.S., K.R. Cooper, G. Olson, E.A. Pena, D.R. Milleman, and R.J. Portier. 2015. Chemical and histological comparisons between Brevoortia sp. (menhaden) collected in fall 2010 from Barataria Bay, LA and Delaware Bay, NJ following the Deepwater Horizon (DWH) oil spill. Marine Environmental Research 112(Part A):21-34, https://doi.org/10.1016/j.marenvres.2015.08.011.

Beyer, J., H.C. Trannum, T. Bakke, P.V. Hodson, and T.K. Collier. 2016. Environmental effects of the Deepwater Horizon oil spill: A review. Marine Pollution Bulletin 110:28-51, https://doi.org/10.1016/ j.marpolbul.2016.06.027.

Boesch, D.F., and N.N. Rabalais, eds. 1987. Long-term Environmental Effects of Offshore Oil and Gas Development. Elsevier Applied Science, New York 708 pp., https://doi.org/10.4324/9780203497777.

Bonisoli-Alquati, A., W. Xu, P.C. Stouffer, and S.S. Taylor. 2020. Transcriptome analysis indicates a broad range of toxic effects of Deepwater Horizon oil on seaside sparrows. Science of the Total Environment 720:137583, https://doi.org/ 10.1016/j.scitotenv.2020.137583.

Brette, F., B. Machado, C. Cros, J.P. Incardona, N.L. Scholz, and B.A. Block. 2014. Crude oil impairs cardiac excitation-contraction coupling in fish. Science 343(6172):772-776, https://doi.org/10.1126/ science.1242747.

Brette, F., H.A. Shiels, G.L.J. Galli, C. Cros, J.P. Incardona, N.L. Schloz, and B.A. Block. 2017. A novel cardiotoxic mechanism for a pervasive global pollutant. Scientific Reports 7:41476, https://doi.org/10.1038/srep41476.

Brewton, R.A., R. Fulford, and R.J. Griffitt. 2013. Gene expression and growth as indicators of effects of the BP Deepwater Horizon oil spill on spotted seatrout (Cynoscion nebulosus). Journal of Toxicology and Environmental Health, Part A 76(21):1,198-1,209, https://doi.org/10.1080/ 15287394.2013.848394.

Brown-Peterson, N.J., M. Krasnec, R. Takeshita, C.N. Ryan, K.J. Griffitt, C. Lay, G.D. Mayer, K.M. Bayha, W.E. Hawkins, I. Lipton, and others. 2015. A multiple endpoint analysis of the effects of chronic exposure to sediment contaminated with Deepwater Horizon oil on juvenile southern flounder and their associated microbiomes. Aquatic Toxicology 165:197-209, https://doi.org/10.1016/ j.aquatox.2015.06.001.

Burns, K.A., and J.M. Teal. 1979. The West Falmouth oil spill: Hydrocarbons in the salt marsh ecosystem. Estuarine and Coastal Marine Science 8:349-360, https://doi.org/10.1016/0302-3524(79)90052-5.

Capuzzo, J.M. 1981. Predicting pollution effects in the marine environment. Oceanus 24:25-33.

Capuzzo, J.M. 1987. Biological effects of petroleum hydrocarbons: Assessments from experimental results. Pp. 343-410 in Long-term Environmental Effects of Offshore Oil and Gas Development. D.F. Boesch and N.N. Rabalais, eds, Elsevier Applied Science, London.

Collier, T.K., and U. Varanasi. 1987. Biochemical indicators of contaminant exposure in flatfish from Puget Sound, WA. Pp. 1,544-1,549 in Proceedings of Oceans '87 IEEE. Washington, DC, https://doi.org/ 10.1109/OCEANS.1987.1160572

Cox, G.K., D.A. Crossley II, J.D. Stieglitz, R.M. Heuer, D.D. Benetti, and M. Grosell. 2017. Oil exposure impairs in situ cardiac function in response to $\beta$-adrenergic stimulation in cobia (Rachycentron canadum). Environmental Science \& Technology 51:14,390-14,396, https://doi.org/ 10.1021/acs.est.7b03820.

Deak, K.L. 2020. A Health Evaluation of Gulf of Mexico Golden Tilefish (Lopholatilus chamaeleonticeps) and Red Snapper (Lutjanus campechanus)
Following the Deepwater Horizon Oil Spill. PhD dissertation, College of Marine Science, University of South Florida, St. Petersburg, FL, 242 pp.

Deepwater Horizon Natural Resource Damage Assessment Trustees. 2016. Deepwater Horizon Oil Spill: Final Programmatic Damage Assessment and Restoration Plan and Final Programmatic Environmental Impact Statement, http://www. gulfspillrestoration.noaa.gov/restoration-planning/ gulf-plan.

De Guise, S., M. Levin, L. Jasperse, J. Herrman, R.S. Wells, T. Rowles, and L. Schwacke. 2021. Longterm immunological alterations in bottlenose dolphin a decade after the Deepwater Horizon oil spill in the Northern Gulf of Mexico: Potential for multigenerational effects. Environmental Toxicology and Chemistry, https://doi.org/10.1002/etc. 4980.

Deis, D.R., J.W. Fleeger, S.M. Bourgoin,

I.A. Mendelssohn, Q. Lin, and A. Hou. 2017. Shoreline oiling effects and recovery of salt marsh macroinvertebrates from the Deepwater Horizon oil spill. PeerJ 5:e3680, https://doi.org/10.7717/ peerj.3680.

Diamante, G., E.G. Xu, S. Chen, E. Mager, M. Grosell, and D. Schlenk. 2017. Differential expression of microRNAs in embryos and larvae of mahi-mahi (Coryphaena hippurus) exposed to Deepwater Horizon oil. Environmental Science \& Technology Letters 4:523-529, https://doi.org/10.1021/acs. estlett.7b00484.

Dubansky, B., A. Whitehead, J.T. Miller, C.D. Rice, and F. Galvez. 2013. Multitissue molecular, genomic, and developmental effects of the deepwater horizon oil spill on resident gulf killifish (Fundulus grandis). Environmental Science \& Technology 47:5,074-5,082, https://doi.org/10.1021/ es400458p.

Esbaugh, A.J., E.M. Mager, J.D. Stieglitz, R. Hoenig, T.L. Brown, B.L. French, T.L. Linbo, H. Forth, N.L. Scholz, J.P. Incardona, and others. 2016. The effects of weathering and chemical dispersion on Deepwater Horizon crude oil toxicity to mahi-mahi (Coryphaena hippurus) early life stages. Science of the Total Environment 543(Part A):644-651, https://doi.org/10.1016/j.scitotenv.2015.11.068.

Fleeger, J.W., K.R. Carman, M.R. Riggio,

I.A. Mendelssohn, Q. Lin, A. Hou, D.R. Deis, and S. Zengel. 2015. Recovery of salt marsh benthic microalgae and meiofauna following the Deepwater Horizon oil spill linked to recovery of Spartina alterniflora. Marine Ecology Progress Series 536:39-54, https://doi.org/10.3354/ meps11451.

Fleeger, J.W., M.R. Riggio, I.A. Mendelssohn, Q. Lin, A. Hou, and D.R. Deis. 2018. Recovery of saltmarsh meiofauna six years after the Deepwater Horizon oil spill. Journal of Experimental Marine Biology and Ecology 502:182-190, https://doi.org/10.1016/ j.jembe.2017.03.001.

Fleeger, J.W., M.R. Riggio, I.A. Mendelssohn, Q. Lin, D.R. Deis, D.S. Johnson, K.R. Carman, S.A. Graham, S. Zengel, and A. Hou. 2019. What promotes the recovery of salt marsh infauna after oil spills? Estuaries and Coasts 4:204-217, https://doi.org/ 10.1007/s12237-018-0443-2.

Fleeger, J.W., D.S. Johnson, S. Zengel, I.A. Mendelssohn, D.R. Deis, S.A. Graham, Q. Lin, M.C. Christman, M.R. Riggio, and M. Pant. 2020. Macroinfauna responses and recovery trajectories after an oil spill differ from those following saltmarsh restoration. Marine Environmental Research 161:105099, https://doi.org/10.1016/ j.marenvres.2020.105099.

Fodrie, F.J., K.W. Able, F. Galvez, K.L. Heck Jr. O.P. Jensen, P.C. López-Duarte, C.W. Martin, R.E. Turner, and A. Whitehead. 2014. Integrating organismal and population responses of 
estuarine fishes in Macondo spill research. BioScience 64(9):778-788, https://doi.org/10.1093/ biosci/biu123.

Frasier, K.E. 2020. Evaluating impacts of deep oil spills on oceanic marine mammals. Pp. 419-441 in Scenarios and Responses to Future Deep Oil Spills: Fighting the Next War. S.A. Murawski, C.H. Ainsworth, S. Gilbert, D.J. Hollander, C.B. Paris, M. Schlüter, and D.L. Wetzel, eds, Springer Nature, https://doi.org/10.1007/978-3-030-12963-7_25.

Frasier, K.E., A. Solsona-Berga, L. Stokes, and J.A. Hildebrand. 2020. Impacts of the Deepwater Horizon oil spill on marine mammals and sea turtles. Pp. 431-462 in Deep Oil Spills: Facts, Fate and Effects. S.A. Murawski, C.H. Ainsworth, S. Gilbert, D.J. Hollander, C.B. Paris, M. Schlüter, and D.L. Wetzel, eds, Springer Nature, https://doi.org/ 10.1007/978-3-030-11605-7.

Garcia, T.I., Y. Shen, D. Crawford, M.F. Oleksiak, A. Whitehead, and R.B. Walter. 2012. RNASeq reveals complex genetic response to Deepwater Horizon oil release in Fundulus grandis. BMC Genomics 13:474, https://doi.org/ 10.1186/1471-2164-13-474.

Garcia, S.M., K.T. Du Clos, O.H. Hawkins, and B.J. Gemmell. 2020. Sublethal effects of crude oil and chemical dispersants on multiple life history stages of the eastern oyster, Crassostrea virginica. Journal of Marine Science and Engineering 8:0808, https://doi.org/10.3390/ jmse8100808.

Gomez, F.M., K.M. Colegrove, W.B. Musser, J.M. Meegan, R. Takeshita, A. Cárdenas Llerenas, T.K. Rowles, L.H. Schwacke, E.D. Jensen, and C.R. Smith. 2020. Potential mechanisms and associated predictors of pregnancy failure in bottlenose dolphins (Tursiops truncatus). Proceedings of the International Association of Aquatic Anima Medicine, Virtual Symposium hosted by the University of Florida.

Goodbody-Gringley, G., D.L. Wetzel, D. Gillon, E. Pulster, A. Miller, and K.B. Ritchie. 2013. Toxicity of Deepwater Horizon source oil and the chemical dispersant, Corexit ${ }^{\circledR} 9500$, to coral larvae. PLoS ONE 8:e45574, https://doi.org/10.1371/journal. pone.0045574.

Grosell, M., R.J. Griffitt, T.A. Sherwood, and D.L. Wetzel. 2020. Digging deeper than LC/EC50: Nontraditional endpoints and non-model species in oil spill toxicology. Pp. 497-514 in Deep Oil Spills: Facts, Fate and Effects. S.A. Murawski, C.H. Ainsworth, S. Gilbert, D.J. Hollander, C.B. Paris, M. Schlüter, and D.L. Wetzel, eds, Springer Nature, https://doi.org/10.1007/978-3-030-11605-7_29.

Grosell, M., and C. Pasparakis. 2021. Physiological responses of fish to oil spills. Annual Reviews in Marine Science 13:137-160, https://doi.org/10.1146/ annurev-marine-040120-094802.

Harrill, J., I. Shah, R.W. Setzer, D. Haggard, S. Auerbach, R. Judson, and R.S. Thomas. 2019. Considerations for strategic use of high-throughput transcriptomics chemical screening data in regulatory decisions. Current Opinions in Toxicology 15:64-75, https://doi.org/10.1016/ j.cotox.2019.05.004.

Heuer, R.M., G. Galli, H. Shiels, L. Fieber, G. Cox, E. Mager, J. Stieglitz, D.D. Benetti, M. Grosell, and D. Crossley. 2019. Impacts of Deepwater Horizon crude oil on Mahi-Mahi (Coryphaena hippurus) heart cell function. Environmental Science and Technology 53(16):9,895-9,904, https://doi.org/ 10.1021/acs.est.9b03798.

Hollenbeck, C.M., D.S. Portnoy, D. Wetzel, T.A. Sherwood, P.B. Samollow, and J.R. Gold. 2017. Linkage mapping and comparative genomics of red drum (Sciaenops ocellatus) using next- generation sequencing. G3 Genes, Genomics, Genetics 7:843-850, https://doi.org/10.1534/ g3.116.036350.

ICCOPR (Interagency Coordinating Committee on Oi Pollution Research). 2015. Oil Pollution Research and Technology Plan, Fiscal Years 2015-2021. 190 pp., https://www.dco.uscg.mil/Portals/9/CG-5R/ ICCOPR/Files/2015-2021 Research and Technology Plan.pdf?ver=2018-01-05-133442-250.

Incardona, J.P., L.D. Gardner, T.L. Linbo, T.L. Brown,

A.J. Esbaugh, E.M. Mager, J.D. Stieglitz, B.L. French, J.S. Labenia, C.A. Laetz, and others. 2014. Deepwater Horizon crude oil impacts the developing hearts of large predatory pelagic fish. Proceedings of the National Academy of Sciences of the United States of America 111(15):1,510-1,518, https://doi.org/10.1073/pnas.1320950111.

Incardona, J.P. 2017. Molecular mechanisms of crude oil developmental toxicity in fish. Archives in Environmental Contamination and Toxicology 73:19-32, https://doi.org/10.1007/ s00244-017-0381-1.

Ivančić, M., F.M. Gomez, W.B. Musser, A. Barratclough, J.M. Meegan, S.M. Waitt, A. Cárdenas Llerenas, E.D. Jensen, and C.R. Smith. 2020. Ultrasonographic findings associated with normal pregnancy and fetal wellbeing in the bottlenose dolphin (Tursiops truncatus). Veterinary Radiology and Ultrasound 61:215-226, https://doi.org/10.1111/ vru.12835.

Johansen, J.L., and A.J. Esbaugh. 2017. Sustained impairment of respiratory function and swim performance following acute oil exposure in a coastal marine fish. Aquatic Toxicology 187:82-89, https://doi.org/10.1016/j.aquatox.2017.04.002.

Kostka, J.E., S.B. Joye, and R.R. Colwell. 2020. Deepwater Horizon and the rise of the omics. EOS:101, https://doi.org/10.1029/2020EO140140.

Khursigara, A.J., P. Perrichon, N., Martinez Bautista, W.W. Burggren, and A.J. Esbaugh. 2017. Cardiac function and survival are affected by crude oil in larval red drum, Sciaenops ocellatus. Science of the Total Environment 579:797-804, https://doi.org/10.1016/j.scitotenv.2016.11.026.

Krahn, M.M., M.S. Myers, L.K. Moore, W.D. MacLeod Jr., and D.C. Malins. 1986 Associations between metabolites of aromatic compounds in bile and the occurrence of hepatic lesions in English sole (Parophrys vetulus) from Puget Sound, Washington. Archives of Environmental Contamination and Toxicology 15:61-67, https://doi.org/10.1007/ BF01055249.

Lin, Q., and I.A. Mendelssohn. 2012. Impacts and recovery of the Deepwater Horizon oil spill on vegetation structure and function of coastal salt marshes in the northern Gulf of Mexico. Environmental Science \& Technology 46(7):3,737-3,743, https://doi.org/ 10.1021/es203552p.

Lin, Q., I.A. Mendelssohn, S.A. Graham, A. Hou, J.W. Fleeger, and D.R. Deis. 2016. Response of salt marshes to oiling from the Deepwater Horizon spill: Implications for plant growth, soil surfaceerosion, and shoreline stability. Science of the Total Environment 557-558:369-377, https://doi.org/ 10.1016/j.scitotenv.2016.03.049.

Linnehan, B.K., A. Hsu, F.M. Gomez, S.M. Huston, R. Takeshita, K.M. Colegrove, T.K. Rowles, A. Barratclough, W.B. Musser, C.A. Harms, and others. 2020. Standardization of dolphin cardiac auscultation and characterization of heart murmurs in managed and free-ranging bottlenose dolphins (Tursiops truncatus). Frontiers in Veterinary Science 7:570055, https://doi.org/10.3389/ fvets. 2020.570055
Lubchenco, J., M.K. McNutt, G. Dreyfus, S.A. Murawski, D.M. Kennedy, P.T. Anastas, S. Chu, and T. Hunter. 2012. Science in support of the Deepwater Horizon response. Proceedings of the National Academy of Sciences of the United States of America 109:20,212-20,221, https://doi.org/ 10.1073/pnas.1204729109.

Mager, E.M., A.J. Esbaugh, J.D. Stieglitz, R. Hoenig, C. Bodinier, J.P. Incardona, N.L. Scholz, D.D. Benetti, and M. Grosell. 2014. Acute embryonic or juvenile exposure to Deepwater Horizon crude oil impairs the swimming performance of mahi-mahi (Coryphaena hippurus). Environmental Science \& Technology 48:7,053-7,061, https://doi.org/10.1021/ es501628k.

Meador, J.P., J.E. Stein, W.L. Reichert, and U. Varanasi. 1995. Bioaccumulation of polycyclic aromatic hydrocarbons by marine organisms. Pp. 79-171 in Reviews of Environmental Contamination and Toxicology. G. Ware, ed., Springer, New York, https://doi.org/10.1007/978-1-4612-2542-3_4.

Mitchelmore, C.L., A.C. Bejarano, and D.L. Wetzel. 2020. A synthesis of DWH oil: Chemical dispersant and chemically dispersed oil aquatic standard laboratory acute and chronic toxicity studies. Pp.480-496 in Deep Oil Spills: Facts, Fate and Effects. S.A. Murawski, C.H. Ainsworth, S. Gilbert, D.J. Hollander, C.B. Paris, M. Schlüter, and D.L. Wetzel, eds, Springer Nature, https://doi.org/ 10.1007/978-3-030-11605-7.

Morano, J.T., J.T. Tielens, C.A. Muirhead, B.J. Estabrook, P.J. Sullivan, P.J. Dugan, C.W. Clark, and A.N. Rice. 2020. Seasonal movements of Gulf of Mexico sperm whales following the Deepwater Horizon oil spill and the limitations of impact assessments. Marine Pollution Bulletin 161:111627, https://doi.org/10.1016/j.marpolbul.2020.111627.

Murawski, S.A., W.T. Hogarth, E.B. Peebles, and L. Barbieri. 2014. Prevalence of external skin lesions and polycyclic aromatic hydrocarbon concentrations in Gulf of Mexico fishes, post-Deepwater Horizon. Transactions of the American Fisheries Society 143(4):1,084-1,097, https://doi.org/10.1080/00028487.2014.911205.

Murawski, S.A., L. Hotaling, S. Gilbert, and D. Yoerger, eds. 2018. Advancing oil detection technologies for the marine ecosystem. Marine Technology Journal 52(6):7, https://doi.org/10.4031/MTSJ.52.6.3.

Murawski, S.A., D. Hollander, S. Gilbert, and A. Gracia. 2020. Deepwater oil and gas production in the Gulf of Mexico and related global trends. Pp. 16-32 in Scenarios and Responses to Future Deep Oil Spills: Fighting the Next War. S.A. Murawski, D. Hollander, C. Ainsworth, S. Gilbert, C.B. Paris, M. Schlüter, and D. Wetzel, eds, Springer Nature, https://doi.org/10.1007/978-3-030-12963-7.

Murawski, S.A., J.P. Kilborn, A.C. Bejarano D. Chagaris, D. Donaldson, F.J. Hernandez Jr. T.C. MacDonald, C. Newton, E. Peebles, and K. Robinson 2021. A synthesis of Deepwater Horizon impacts on coastal and nearshore living marine resources. Frontiers in Marine Science 7:594862, https://doi.org/10.3389/ fmars.2020.594862.

Myers, M.S., C.M. Stehr, O.P. Olson, L.L. Johnson, B.B. McCain, S.L. Chan, and U. Varanasi. 1994 Relationships between toxicopathic hepatic lesions and exposure to chemical contaminants in English sole (Pleuronectes vetulus), starry flounder (Platichthys stellatus), and white croaker (Genyonemus lineatus) from selected marine sites on the Pacific Coast, USA. Environmental Health Perspectives 102:200-215, https://doi.org/10.1289/ ehp.94102200. 
NASEM (National Academies of Science, Engineering and Medicine). 2020. The Use of Dispersants in Marine Oil Spill Response. The National Academies Press, Washington, DC, 340 pp., https://doi.org/ 10.17226/25161

Nelson, D., R.M. Heuer, G.K. Cox, J.D. Stieglitz, R. Hoenig, E.M. Mager, D.D. Benetti, M. Grosell, and D.A. Crossley II. 2016. Effects of crude oil on in situ cardiac function in young adult mahi-mahi (Coryphaena hippurus). Aquatic Toxicology 180:274-81, https://doi.org/10.1016 j.aquatox.2016.10.012

Nelson, D., J.D. Stieglitz, G.K. Cox, R.M. Heuer, D.D. Benetti, M. Grosell, and D.A. Crossley II. 2017. Cardio-respiratory function during exercise in the cobia, Rachycentron canadum: The impact of crude oil exposure. Comparative Biochemistry and Physiology C: Toxicology \& Pharmacology 201:58-65, https://doi.org/10.1016/ j.cbpc.2017.08.006.

NRC (National Research Council). 1985. Oil in the Sea Inputs, Fates, and Effects. National Academies Press, Washington, DC, 581 pp., https://doi.org/ 10.17226/314.

Okey, A.B. 2007. An aryl hydrocarbon receptor odyssey to the shores of toxicology: The Deichmann Lecture, International Congress of Toxicology-XI. Toxicological Sciences 98:5-38, https://doi.org/ 10.1093/toxsci/kfm096.

Omar-Ali, A., C. Hohn, P.J. Allen, J. Rodriguez, and L. Petrie-Hanson. 2015. Tissue PAH, blood cell and tissue changes following exposure to water accommodated fractions of crude oil in alligator gar, Atractosteus spatula. Marine Environmental Research 108:33-44, https://doi.org/10.1016/ j.marenvres.2015.04.011.

Park, B.S., D.L. Erdner, H.P. Bacosa, Z. Liu, and E.J. Buskey. 2020. Potential effects of bacterial communities on the formation of blooms of the harmful dinoflagellate Prorocentrum after the 2014 Texas City "Y" oil spill (USA). Harmful Algae 95:101802, https://doi.org/10.1016/ j.hal.2020.101802.

Peacock, E.E., R.K. Nelson, A.R. Solow, J.D. Warren, J.L. Baker, and C.M. Reddy. 2005. The West Falmouth oil spill: $\sim 100 \mathrm{~kg}$ of oil found to persist decades later. Environmental Forensics 6:273-281, https://doi.org/10.1080/15275920500194480.

Peiffer, R., and J. Cohen. 2015. Lethal and sublethal effects of oil, chemical dispersant, and dispersed oil on the ctenophore Mnemiopsis leidyi. Aquatic Biology 23:237-250, https://doi.org/10.3354/ ab00625.

Perrichon, P., E.M. Mager, C. Pasparakis, J.D. Stieglitz, D.D. Benetti, M. Grosell, and W.W. Burggren. 2018 Combined effects of elevated temperature and Deepwater Horizon oil exposure on the cardiac performance of larval mahi-mahi, Coryphaena hippurus. PLoS ONE 13:e0203949, https://doi.org/ 10.1371/journal.pone.0203949.

Peterson, C.H., S.D. Rice, J.W. Short, D. Esler, J.L. Bodkin, B.E. Ballachey, and D.B. Irons. 2003. Long-term ecosystem response to the Exxon Valdez oil spill. Science 302:2,082-2,086, https://doi.org/10.1126/science.1084282.

Powers, S.P., C.H. Peterson, J. Cebrian, and K.L. Heck Jr. 2017. Response of nearshore ecosystems to the Deepwater Horizon spill. Marine Ecology Progress Series 576:107-110, https://doi.org/10.3354/ meps12254.

Pulster, E.L., K. Main, D. Wetzel, and S. Murawski. 2017. Species-specific metabolism of naphthalene and phenanthrene in 3 species of marine teleosts exposed to Deepwater Horizon crude oil. Environmental Toxicology and Chemistry 36:3,168-3,176, https://doi.org/10.1002/ etc.3898.
Pulster, E.L., A. Gracia, M. Armenteros, B.E. Carr, J. Mrowicki, and S.A. Murawski. 2020a. Chronic $\mathrm{PAH}$ exposures and associated declines in fish health indices observed for ten grouper species in the Gulf of Mexico. Science of the Total Environment 703:135551, https://doi.org/10.1016/ j.scitotenv.2019.135551.

Pulster, E.L., A. Gracia, M. Armenteros, G. ToroFarmer, S.M. Snyder, B.E. Carr, M.R. Schwaab, T.J. Nicholson, J. Mrowicki, and S.A. Murawski. 2020b. A first comprehensive baseline of hydrocarbon pollution in Gulf of Mexico fishes. Scientific Reports 10:6437, https://doi.org/10.1038/ s41598-020-62944-6.

Pulster, E.L., A. Gracia, S.M. Snyder, K. Deak, S.B. Fogelson, and S.A. Murawski. 2020c. Chronic sub-lethal effects observed in wildcaught fishes following two major oil spills in the Gulf of Mexico: Deepwater Horizon and Ixoc 1. Pp. 388-413 in Deep Oil Spills: Facts, Fate and Effects. S.A. Murawski, C.H. Ainsworth, S. Gilbert, D.J. Hollander, C.B. Paris, M. Schlüter, and D.L. Wetzel, eds, Springer Nature, https://doi.org/ 10.1007/978-3-030-11605-7_24.

Pulster, E.L., A. Gracia, S.M. Snyder, I.C. Romero, B. Carr, G.A. Toro-Farmer, and S.A. Murawski. 2020d. Polycyclic aromatic hydrocarbon baselines in Gulf of Mexico fishes. Pp. 253-271 in Scenarios and Responses to Future Deep Oil Spills: Fighting the Next War. S.A. Murawski, C.H. Ainsworth, S. Gilbert, D.J. Hollander, C.B. Paris, M. Schlüter, and D.L. Wetzel, eds, Springer Nature, https://doi.org/10.1007/978-3-030-12963-7_15.

Pulster, E.L., S. Fogelson, B.E. Carr, J. Mrowicki, and S.A. Murawski. 2021. Hepatobiliary PAHs and prevalence of pathological changes in red snapper. Aquatic Toxicology 230:105714, https://doi.org/ 10.1016/j.aquatox.2020.105714.

Radović, J.R., I.C. Romero, T.B.P. Oldenburg, S.R. Larter, and J.W. Tunnell Jr. 2020. 40 years of weathering of coastal oil residues in the south ern Gulf of Mexico. Pp. 328-340 in Deep Oil Spills: Facts, Fate and Effects. S.A. Murawski, C.H. Ainsworth, S. Gilbert, D.J. Hollander, C.B. Paris, M. Schlüter, and D.L. Wetzel, eds, Springer Nature, https://doi.org/10.1007/978-3-030-11605-7_20.

Reddy, C.M., T.L. Eglinton, A. Hounshell, H.K. White, L. Xu, R.B. Gaines, and G.G. Frysinger. 2002. The West Falmouth oil spill after thirty years: The persistence of petroleum hydrocarbons in marsh sediments. Environmental Science \& Technology 36:4,754-4,760, https://doi.org/10.1021/ es020656n.

Rice, S.D., R.B. Spies, D.A. Wolfe, and B.A. Wright, eds. 1996. Proceedings of the Exxon Valdez Oil Spill Symposium. American Fisheries Society, Bethesda, MD, $931 \mathrm{pp}$

Robertson, M., A. Schrey, A. Shayter, C.J. Moss, and C. Richards. 2017. Genetic and epigenetic variation in Spartina alterniflora following the Deepwater Horizon oil spill. Evolutionary Applications 10:792-801, https://doi.org/10.1111 eva.12482.

Rodgers, M.L., T.A. Sherwood, A.M. Tarnecki, R.J. Griffitt, and D.L. Wetzel. 2021. Characterizing transcriptomic responses of southern flounder (Paralichthys lethostigma) chronically exposed to Deepwater Horizon oiled sediments. Aquatic Toxicology 230:105716, https://doi.org/10.1016/ j.aquatox.2020.105716.

Romero, I.C., T.T. Sutton, B. Carr, E. Quintana-Rizzo, S.W. Ross, D.J. Hollander, and J.J. Torres. 2018. Decadal assessment of polycyclic aromatic hydrocarbons in mesopelagic fishes from the Gulf of Mexico reveals exposure to oil-derived sources. Environmental Science \& Technology 52:10,985-10,996, https://doi.org/ 10.1021/acs.est.8b02243.
Romero, I.C., H. Judkins, and M. Vecchione. 2020. Temporal variability of polycyclic aromatic hydrocarbons in deep-sea cephalopods of the northern Gulf of Mexico. Frontiers in Marine Science 7:54, https://doi.org/10.3389/fmars.2020.00054.

Sanders, H.L., J.F. Grassle, G.R. Hampson, L.S. Morse, S. Garner-Price, and C.C. Jones. 1980. Anatomy of an oil spill: Long-term effects from the grounding of the barge Florida off West Falmouth, Massachusetts. Journal of Marine Research 38:265-380.

Schlenker, L.S., M.J. Welch, T.L. Meredith, E.M. Mager, E. Lari, E.A. Babcock, G.G. Pyle, P.L. Munday, and M. Grosell. 2019a. Damsels in distress: Oil exposure modifies behavior and olfaction in bicolor damselfish (Stegastes partitus). Environmental Science \& Technology 53:10,993-11,001, https://doi.org/10.1021/acs.est.9b03915.

Schlenker, L.S., M.J. Welch, T.L. Meredith,

E.M. Mager, J.D. Stieglitz, D.D. Benetti, P.L. Munday, and M. Grosell. 2019b. Exposure to crude oil from the Deepwater Horizon oil spill impairs oil avoidance behavior without affecting olfactory physiology in juvenile mahi-mahi (Coryphaena hippurus). Environmental Science \& Technology 53:14,001-14,009, https://doi.org/ 10.1021/acs.est.9b05240.

Schwing, P.T., P.A. Montagna, S.B. Joye, C.B. Paris, E.E. Cordes, C.R. McClain, J.P. Kilborn, and S.A. Murawski. 2020. A synthesis of deep benthic faunal impacts and resilience following the Deepwater Horizon oil spill. Frontiers in Marine Science 7:560012, https://doi.org/10.3389/ fmars.2020.560012.

Sherwood, T.A., R.L. Medvecky, C.A. Miller, A.M. Tarnecki, R.W. Schloesser, K.L. Main, C.L. Mitchelmore, and D.L. Wetzel. 2017. Nonlethal biomarkers of oxidative stress in oiled sediment exposed southern flounder (Paralichthys lethostigma): Utility for field-base monitoring exposure and potential recovery. Environmental Science \& Technology 53:14,734-14,743, https://doi.org/ 10.1021/acs.est.9b05930.

Smith, C.R., T.K. Rowles, L.B. Hart, F.I. Townsend, R.S. Wells, E.S. Zolman, B.C. Balmer, B. Quigley, M. Ivančić, W. McKerche, and others. 2017. Slow recovery of Barataria Bay dolphin health following the Deepwater Horizon oil spill (2013-2014), with evidence of persistent lung disease and impaired stress response. Endangered Species Research 33:127-142, https://doi.org/10.3354/ esr00778.

Smith, C.R., F.M. Gomez, K.M. Colegrove, T.K. Rowles, E.S. Zolman, T.R. Speakman, A. Barratclough, W.B. Musser, B.C. Balmer, R. Takeshita, and others. 2020. Sustained maternal illness and low reproductive success rate in Barataria Bay bottlenose dolphins (Tursiops truncatus) following the Deepwater Horizon oil spill. Proceedings of the International Association of Aquatic Animal Medicine. Virtual symposium hosted by the University of Florida. Smith, C.R., T.K. Rowles, F.M. Gomez, K.M. Colegrove, R. Takeshita, E.S. Zolman, B.C. Balmer, R.S. Wells, F.I. Townsend, J.S. Morey, and others. 2021. Persistence of poor pulmonary health in dolphins living within the Deepwater Horizon oil spill footprint. Proceedings of the International Oil Spill Conference (virtual).

Snyder, S.M., E.L. Pulster, D.L. Wetzel, and

S.A. Murawski. 2015. PAH exposure in Gulf of Mexico demersal fishes, postDeepwater Horizon. Environmental Science \& Technology 49(14):8,786-8,795, https://doi.org/ 10.1021/acs.est.5b01870.

Snyder, S.M., E.L. Pulster, and S.A. Murawski. 2019. Associations between chronic exposure to polycyclic aromatic hydrocarbons and health indices in Gulf of Mexico tilefish (Lopholatilus chamaele- 
onticeps) post Deepwater Horizon. Environmental Toxicology and Chemistry 38:2,659-2,671, https://doi.org/10.1002/etc.4583.

Snyder, S.M. 2020. Polycyclic Aromatic Hydrocarbon Exposure, Hepatic Accumulation, and Associated Microscopic Hepatic Changes in Gulf of Mexico Tilefish (Lopholatilus chamaeleonticeps). PhD dissertation, University of South Florida, College of Marine Science, $180 \mathrm{pp}$

Snyder, S.M., J.A. Olin, E.L. Pulster, and S.A. Murawski. 2020. Spatial contrasts in hepatic and biliary PAHs in tilefish (Lopholatilus chamaeleonticeps) throughout the Gulf of Mexico, with comparison to the Northwest Atlantic. Environmental Pollution 258:113775, https://doi.org/10.1016/ j.envpol.2019.113775.

Stegeman, J.J., J.J. Schlezinger, J.E. Craddock, and D.E. Tillitt. 2001. Cytochrome P450 1A expression in midwater fishes: Potential effects of chemical contaminants in remote oceanic zones. Environmental Science \& Technology 35:54-62, https://doi.org/ 10.1021/es0012265.

Stein, J.E., W.L. Reichert, M. Nishimoto, and U. Varanasi. 1990. Overview of studies on liver carcinogenesis in English sole from Puget Sound; evidence for a xenobiotic chemical etiology II: Biochemical studies. Science of the Total Environment 94:51-69, https://doi.org/ 10.1016/0048-9697(90)90364-Z.

Stieglitz, J.D., E.M. Mager, R.H. Hoenig, D.D. Benetti, and M. Grosell. 2016a. Impacts of Deepwater Horizon crude oil exposure on adult mahimahi (Coryphaena hippurus) swim performance. Environmental Toxicology and Chemistry 35:2,613-2,622, https://doi.org/10.1002/ etc.3436.

Stieglitz, J.D., E.M. Mager, R.H. Hoenig, M. Alloy, A.J. Esbaugh, C. Bodinier, D.D. Benetti, A.P. Roberts, and M. Grosell. 2016b. A novel system for embryo-larval toxicity testing of pelagic fish: Applications for impact assessment of Deepwater Horizon crude oil. Chemosphere 162:261-268, https://doi.org/10.1016/j.chemosphere.2016.07.069.

Sutton, T.T., T. Frank, H. Judkins, and I.C. Romero. 2020. As Gulf oil extraction goes deeper, who is at risk? Community structure, distribution, and connectivity of the deep-pelagic fauna. Pp. 403-418 in Scenarios and Responses to Future Deep Oil Spills. S.A. Murawski, C.H. Ainsworth, S. Gilbert, D.J. Hollander, C.B. Paris, M. Schlüter, and D.L. Wetzel, eds, Springer Nature, https://doi.org/ 10.1007/978-3-030-12963-7_24.

Teal, J.M., J.W. Farrington, K.A. Burns, J.J. Stegeman, B.W. Tripp, B. Woodin, and C. Phinney. 1992. The West Falmouth oil spill after 20 years: Fate of fuel oil compounds and effects on animals. Marine Pollution Bulletin 24:607-614, https://doi.org/ 10.1016/0025-326X(92)90281-A

Thomas, R.E., and S.D. Rice. 1987. Effect of watersoluble fraction of Cook Inlet crude oil on swimming performance and plasma cortisol in juvenile coho salmon (Oncorhynchus kisutch). Comparative Biochemistry and Physiology C 87:177-180, https://doi.org/10.1016/0742-8413(87)90200-3.

Transportation Research Board and Nationa Research Council. 2003. Oil in the Sea III: Inputs, Fates, and Effects. National Academies Press, Washington, DC, 277 pp., https://doi.org/10.17226/ 10388.

Turner, N.R. 2020. Understanding the Toxicity of Single Hydrocarbons, Oil, and Dispersed Oil: A Species Sensitivity Assessment for Five Atlantic Coral Species. PhD dissertation, Nova Southeastern University, FL.

Turner, R.E., N.N. Rabalais, E.B. Overton, B.M. Meyer G. McClenachan, E.M. Swenson, M. Besonen, M.L. Parsons, and J. Zingre. 2019. Oiling of the continental shelf and coastal marshes over eight years after the 2010 Deepwater Horizon oil spill. Environmental Pollution 252:1,367-1,376, https://doi.org/10.1016/j.envpol.2019.05.134.

Varanasi, U., D.J. Gmur, and P.A. Treseler. 1979. Influence of time and mode of exposure on biotransformation of naphthalene by juvenile starry flounder (Platichthys stellatus) and rock sole (Lepidopsetta bilineata). Archives of Environmental Contamination and Toxicology 8:673-692, https://doi.org/10.1007/BF01054869.

Varanasi, U., J.E. Stein, M. Nishimoto, W.L. Reichert, and T.K. Collier. 1987. Chemical carcinogenesis in feral fish: Uptake, activation, and detoxication of organic xenobiotics. Environmental Health Perspectives 71:155-170, https://doi.org/10.1289/ ehp.8771155.

Wagner, H.-J. 2001. Sensory brain areas in mesopelagic fishes. Brain, Behavior and Evolution 57:117-133, https://doi.org/10.1159/ 000047231

White, P.A., S. Robitaille, and J.B. Rasmussen. 1999. Heritable reproductive effects of Benzo[a] pyrene on the fathead minnow (Pimephales promelas). Environmental Toxicology and Chemistry 18:1,843-1,847, https://doi.org/10.1002/ etc. 5620180835

Whitehead, A., B. Dubansky, C. Bodiner, T.I. Garcia, S. Miles, C. Pilley, V. Raghunathan, J.L. Roach, N. Walker, R.B. Walter, and others 2012. Genomic and physiological footprint of the Deepwater Horizon oil spill on resident marsh fishes. Proceedings of the Nationa Academy of Sciences of the United States of America 109(50):20,298-20,302, https://doi.org/ 10.1073/pnas.1109545108.

Whitehead, A., B.W. Clark, N.M. Reid, M.E. Hahn, and D. Nacci. 2017. When evolution is the solution to pollution: Key principles, and lessons from rapid repeated adaptation of killifish (Fundulus heteroclitus) populations. Evolutionary Applications 10:762-783, https://doi.org/10.1111/ eva.12470.

Wiesenburg, D.A., B. Shipp, F.J. Fodrie, S. Powers, J. Lartigue, K.M. Darnell, M.M. Baustian, C. Ngo, J.F. Valentine, and K. Wowk. 2021. Prospects for Gulf of Mexico environmental recovery and restoration. Oceanography 34(1):164-173, https://doi.org/10.5670/oceanog.2021.124.

Xu, E.G., E.M. Mager, M. Grosell, C. Pasparakis, L.S. Schlenker, J.D. Stieglitz, D. Benetti, E.S. Hazard, S.M. Courtney, G. Diamante, and others. 2016. Time- and oil-dependent transcrip tomic and physiological responses to Deepwater Horizon oil in mahi-mahi (Coryphaena hippurus) embryos and larvae. Environmental Science \& Technology 50:7,842-7,851, https://doi.org/10.1021/ acs.est.6b02205.

Xu, E.G., E.M. Mager, M. Grosell, E.S. Hazard G. Hardiman, and D. Schlenk. 2017a. Novel transcriptome assembly and comparative toxicity pathway analysis in mahi-mahi (Coryphaena hippurus) embryos and larvae exposed to Deepwater Horizon oil. Scientific Reports 7:44546, https://doi.org/10.1038/srep44546.

Xu, E.G., A.J. Khursigara, J. Magnuson, E.S. Hazard, G. Hardiman, A.J. Esbaugh, A.P. Roberts, and D. Schlenk. 2017b. Larval red drum (Sciaenops ocellatus) sublethal exposure to weathered Deepwater Horizon crude oil: Developmental and transcriptomic consequences. Environmental Science \& Technology 51:10,162-10,172, https://doi.org/10.1021/acs.est.7b02037.

Yednock, B.K., T.J. Sullivan, and J.E. Neigel. 2015 De novo assembly of a transcriptome from juvenile blue crabs (Callinectes sapidus) follow- ing exposure to surrogate Macondo crude oil. BMC Genomics 16:521, https://doi.org/10.1186/ s12864-015-1739-2.

Zimmer, R.K., and C.A. Butman. 2000. Chemical sig naling processes in the marine environment. Biological Bulletin 198:168-187, https://doi.org/ 10.2307/1542522.

\section{ACKNOWLEDGMENTS}

This synthesis is part of an ongoing effort to develop an overview and essential messaging from the research program supported by the Gulf of Mexico Research Initiative. We appreciate careful manuscript reviews by J. Farrington, S. Snyder, and E. Pulster and two anonymous reviewers, as well as editorial assistance of S. Gilbert. The illustration in Figure 1 was re-crafted by N. Renier, of the Woods Hole Oceanographic Institution, and we acknowledge use of the photographs by D. Fenolio in Figure 7. A number of colleagues contributed to specific sec tions of this overview, including Irv Mendelssohn, Patrick Schwing, and Abbey Renegar.

\section{AUTHORS}

Steven A. Murawski (smurawski@usf.edu) is Professor, College of Marine Science, University of South Florida, St. Petersburg, FL, USA Martin Grosell is Professor, Department of Marine Biology and Ecology, Rosenstiel School of Marine and Atmospheric Science, University of Miami, Miami, FL, USA. Cynthia Smith is Executive Director, National Marine Mammal Foundation, San Diego, CA USA. Tracey Sutton is Professor, Oceanic Ecology Laboratory, Halmos College of Arts \& Sciences, Nova Southeastern University, Fort Lauderdale, FL, USA. Kenneth M. Halanych is Professor, Department of Biological Sciences, Auburn University, Auburn, AL, USA. Richard F. Shaw is Professor Emeritus, College of the Coast \& Environment, Louisiana State University, Baton Rouge, LA, USA. Charles A. Wilson is Chief Scientific Officer, Gulf of Mexico Research Initiative, Fairhope, AL, USA.

\section{ARTICLE CITATION}

Murawski, S.A., M. Grosell, C. Smith, T. Sutton, K.M. Halanych, R.F. Shaw, and C.A. Wilson. 2021. Impacts of petroleum, petroleum components, and dispersants on organisms and populations. Oceanography 34(1):136-151, https://doi.org/10.5670/ oceanog.2021.122.

\section{COPYRICHT \& USACE}

This is an open access article made available under the terms of the Creative Commons Attribution 4.0 International License (https://creativecommons.org/ licenses/by/4.0/), which permits use, sharing, adaptation, distribution, and reproduction in any medium or format as long as users cite the materials appropriately, provide a link to the Creative Commons license, and indicate the changes that were made to the original content. 